\title{
The Regulation of Graft Abnormalities in Hydra ${ }^{1}$.
}

\author{
By \\ Herbert W. Rand. \\ With Plates V-VII. \\ Eingegangen am 7. Juli 1899.
}

\section{Introduction.}

In a previous paper I have described a series of experiments on regeneration in Hydra viridis (RAND, 1899. In these experiments it was found that, in the regeneration of "heads severed just below the tentacle ring, tentacles which came to lie in an abnormal position on the trunk of the animal were gradually reduced in volume and finally disappeared by what was apparently a process of resorption.

This resorption of abnormal tentacles was observed, not only in the case of tentacles placed at the extreme aboral end of the trunk, but even in the case of those that were at no great distance below the oral group of tentacles. When this distance was very small, - one half the diameter of the Hydra, perhaps, - but only then, the normal condition was regained by the shifting of the abnormal tentacle up into the plane of the oral group. Some of the abnormally placed tentacles became greatly enlarged in the early stages of the regeneration of the animal, so that in some cases the regulative processes involved the resorption of a much greater mass of tissue than is contained in a normal tentacle.

Most of the abnormalities which thus disappeared consisted of organs which could not possibly exercise their normal functions in the abnormal positions. A tentacle situated not very far below the

1) Contributions from the Zoulogical Laboratory of the Museum of Comparative Zoülogy at Harvard College. E. L. MARK, Director. No. 102. 
oral ring might be used for the capture of food; yet it certainly could not be quite as useful as one in a perfectly normal position. If, as was often the case, a normal tentacle is placed above the abnormal one and in the same radial plane, the chance for usefulness in the abnormal tentacle is still smaller.

Such organs, useless or nearly so to the animal, must nevertheless draw upon the food supply of the organism for their maintenance, if they persist. The question therefore arises: What will be the fate of similarly placed abnormalities which, although they may not be of advantage to the animal, will nevertheless not be dependent upon it for food supply?

Abnormalities of this sort can be obtained by grafting the upper part of one Hydra into the side of the trunk of another, a branched or double-headed polyp resulting. There is no obvious reason why such a form should not be a permanent one.

A graft possessing a digestive cavity, hypostome and tentacles of its own would appear to be situated as advantageously for the carrying on of its life processes while attached to the side of another Hydra, as is a Hydra attached to the stem of a plant or to some lifeless object, although in the latter case there is only adhesion of the polyp's foot to the substratum, while the tissues of the graft are in organic comnection with the corresponding tissues of the Hydra bearing the graft. In the compound polyp produced by grafting, whatever advantages are derived from locomotion must be shared by the two trunks and heads borne upon the common foot. If the graft abnormality is self-supporting, so that no draft is made upon the food supply of the Hydra bearing the graft, there is no apparent necessity for either the graft, or the polyp bearing it, entering upon a series of processes to effect separation. Will this abnormal form, then, persist, or are there factors, not apparent in the metabolic economy of the organisms, which will insist upon the removal of the abnormality and the regaining of normal conditions? A Hydra bearing a lateral graft might come to resemble closely a budding: polyp. If the graft should be ultimately separated from the polyp bearing it, will the process of separation be similar to that of a bud from the parent, or will a peculiar method of effecting the separation be found? Such are some of the questions which I have attempted to answer by experiment. 


\section{Material.}

Hydra riridis was ased in all of the experiments except numbers 1, 26, 27 and 37 , in which the larger brown Hydra (fusca?) was used. For the purpose of these experiments the green Hydras possessed a great advantage over the brown ones, owing to the comparative quickness with which the regulative processes were carried out in the former. It is with some difficulty that Hydras which have been operated upon are kept in good condition in a laboratory through long periods of time. It is therefore desirable that the experiments should not extend over too much time. The behavior of the few individuals of Hydra fusea which I operated upon was preeisely like that of green $\mathrm{Hydras}$ which had been similarly treated, except in point of time. If Experiments 1 and 2 be compared, it will be seen that the brown Hydra required 52 days to effect changes that Hydra viridis accomplished in 23 days. It has been noticed by others, too, that Hydra viridis regenerates much faster than Hydra fusca.

Hydra riridis was found in great abundance during the winter months in masses of algae dredged up from a pond in Cambridge. Aquaria in the laboratory were stocked from this source and some of the cultures remained in good condition throughout the winter. The brown species was comparatively scarce.

The smallness of the green Hydras was the chief obstacle to their employment. The more difficult grafts could have been made much more readily upon the large brown Hydras.

\section{Methods.}

\section{Grafting.}

The grafting of the larger brown Hydras was accomplished by impaling them upon bristles after the manner described by Wetzes (1895). This method was also tried with the green Hydras, but it was found that some more delicate means of operating upon these smaller polyps was necessary. Several methods of holding the pieces together during the union of the tissues were tried, but only the paraffin method, which I shall describe, was successful; by it all but two or three of the grafts were made.

The botton of a small Stender dish was covered with a film of soft paraffin having a thickness rather greater than the diameter 
of a Hydra when contracted. In such a dish, two-thirds full of fresh tap water, and placed upon the stage of a dissecting microscope, all of the cutting and grafting operations were performed.

Several Hydras were placed in the dish. Then, with a rather blunt needle, grooves were scratched in the paraffin in such a way as to make a mold suited in size and shape to the form of the graft which it was desired to obtain. As regards orientation the grafts were of two kinds: 1) those in which the pieces were brought together in the same axis, - end to end grafts, and 2) those in which the long axes of the two pieces were at right angles to each other, - perpendicular grafts. For grafts of the first kind, a single straight groove was made, of a width slightly less than the diameter of a contracted Hydra, and of a length perhaps one-half greater than the combined length of the two pieces, moderately contracted, which were to be united. If the pieces bore no tentacles, the grooves were scratched through the entire thickness of the paraffin, so as to secure good illumination from below. The Hydras were not cut until the mold had been prepared, as the union of the tissues was most easily effected when the surfaces in contact were freshly cut.

The desired cuts were made either with a thin, narrow scalpel, or with a needle whose end had been ground down flat and to a cutting edge. The paraffin film formed a very good surface upon which to do the cutting. As quickly as possible after the cutting, the pieces to be united were conveyed to the groove and, with a blunt needle, carefully pressed down into it, end to end in the desired orientation. In spite of the cutting and the subsequent pushing about with a needle, the pieces will begin to elongate within a few seconds after being placed in the groove. When they have elongated so as to fill the entire length of the groove, the subsequent effort to extend results in pressing together more firmly the uniting surfaces. The ends of the groove were slightly hollowed out under the surface of the paraffin, so that when the end of a Hydra reached the end of the groove, it was caught in this concavity and did not slide up out of the groove. Continued lengthening will cause the pieces to buckle upwards out of the groore, in, which event they are very likely to be broken apart. It is therefore necessary to watch the pieces closely, and when the tendency to buckle appears, the needle point must be there to prevent it or to administer a gentle stimulus which will either prevent further elongation, or cause slight contraction. The contraction is quite apt to be too violent, in which 
case the pieces may be torn apart and must again be brought together. It was sometimes possible, by means of light needle touches judiciously administered, to keep the pieces at about the optimum condition of expansion until firmly united ${ }^{1}$ ). Sometimes the groove was partly bridged over with bits of paraffin to assist in keeping the pieces within bounds. The groove might have been made so short as to admit of no elongation of the pieces, but it was found easier to be sure of proper orientation, if the pieces were allowed to partly extend.

In the grafts of the second class, the operation consisted in grafting a comparatively short piece into the side of the trunk of a whole Hydra, and at right angles to it. For this purpose one groove was made for the whole Hydra somewhat narrower than the contracted diameter of the polyp and long enough to admit of its fullest extension. At the middle of this groove, a second groove, at right angles to the first and opening into it, was made for the reception of the graft (Figs. $1 a$ and $1 b$ ). In the case of large Hydras with strong tentacles it was found best to have the paraffin considerably thicker than the animals. The grooves were then made through only part of the thickness of the paraffin, except in the region to be occupied by the shead « of the animal, where the groove was deepened to admit the tentacles, thus allowing the trunk to lie flat in the shallower part of the groove. It was also desirable to have the longer groove oblique to the surface of the paraffin, as shown in Fig. 1 b. By this obliquity of the groove, the pressing of

1) In this connection may be mentioned a condition resembling muscular exhaustion, which I have noticed to occur in Hydra, as a result of frequently repeated tactile stimulations. A normal extended Hydra contracts in response to touch. If the stimulus is weak, the contraction is partial; a sufficiently strong stimulus, or a succession of weaker ones, causes maximum contraction. If a Hydra in this condition of maximum contraction be stimulated by touching about the hypostome and tentacles with the point of a needle, two or three times per second, it will after a few seconds begin to extend and may reach the condition of maximum extension during the application of the stimuli. If the stimulation continues without interruption, the extended Hydra will show no response. If the touches have been vigorous, the polyp may be knocked about quite violently withont contracting. In a few seconds after the stimuli have ceased to be applied, the Hydra will respond normally by contracting. Hydras in poor condition as a result of unfavorable aquarium conditions sometimes show a similar failure to respond to stimuli. I have found such polyps with trunk and tentacles fully extended, but perfectly rigid and unresponsive to the most violent tactile stimuli. 
the graft against the side of the whole Hydra is made to keep the Hydra more firmly in place in its groove.

The mold being ready, the piece to be grafted was cut from one Hydra. The other Hydra was then placed in its groove, the point at which the graft was to be inserted being at the end of the smaller groove. At this point a break in the body-wall of the Hydra was made with the point of a needle. The graft was then quickly brought into position in its groove, with its cut end pressed closely against the wound in the trunk of the other Hydra, and was held there until well united.

If union did not result in the first attempt, it was generally found best to begin again with new pieces, unless at least one of the old ones could be again cut so as to secure a fresh surface. Two newly cut surfaces brought immediately into good contact adhere almost instantaneously, although at first the adhesion is rery weak and a slight pull is sufficient to separate them. After ten minutes the animals could generally be safely removed from the mold, and after fifteen minutes to an hour they were transferred with a pipette from the operating dish to the dish in which they were to be kept.

All of the rather minute details which have been mentioned in the foregoing description were found to be important, if not necessary, to the success of the operation. Under the most favorable conditions every successful graft represented several unsuccessful attempts.

Observations were made at frequent intervals, - daily during the earlier stages of most of the experiments. When the progress of the changes taking place was very slow, observations were made less frequently. At the times of observation drawings were made as accurately as possible, but without the aid of the camera, for the Hydras are constantly changing form and swinging about. The drawings, unless otherwise noted, represent the polyps in a condition of moderate extension.

\section{Aquaria.}

In my former experiments upon Hydras, I depended upon the frequent changing of the water to keep them in good condition. In the present series of experiments I endeavored rather to obtain an equilibrium of conditions in the small aquaria in which the Hydras were kept. The grafted polyps were put in small Stender dishes (only one or two in a dish) two-thirds full of tap water. A small quantity of fresh, green, filamentous algae, carefully examined to see 
that it contained no other Hydras, was added. Food material, other than that which might be in the water or in the algae, was not in all cases provided. In the experiments that extended over the longer periods of time, small Entomostraca were occasionally added, or a few drops of a rich eulture of Paramoecia or large Hypotricha. The dishes were kept covered, but not tightly. In this manner was obtained, in many cases, an equilibrium of conditions apparently favorable to the Hydras, and continuing through many days or eren weeks. As long as the conditions appeared farorable, the water was not changed. If bacterial growths became too abundant, the dish was cleansed and fresh water and fresh algae put in. A proper quantity of the algae seems to be effective in maintaining the oxygen tension in the water. In respect to bacteria the condition of the water is also much improved by the presence of the algae, at least so far as bacteria harmful to the Hydras are concerned. In my former experiments it was very often found that within even fortyeight hours after the Hydras had been put into thoroughly eleansed dishes of fresh water, bacterial growths would appear in considerable quantities, frequently encumbering the tentacles of the animals. In the presence of algae this very rarely happened. Eren when a scum, apparently of a bacterial nature, did form on the bottom of the dish, the Hydras were not attacked. After I had determined roughly the favorable conditions, the mortality among the polyps under observation was considerably lower than in my former series of experiments. Of a total of fifty-one experiments, death occurred in fifteen cases. Six of these deaths occurred in the first nine experiments leaving the remaining nine deaths scattered through fortytwo experiments. In most of the fifteen cases death occurred two to four weeks after the operation. I have read with interest the work of Vernon (1898) dealing with equilibrium of conditions in marine aquaria. My observations on the effects of fresh water algae agree with his on the effects of Ulva in sea water.

The small green Hydras were often seen to capture Entomostraca and larvae of relatively large size. I never saw a Hydra actually swallow any of the large Infusoria which $I$ put in the Stender dishes. But in most cases the addition of a few drops of the Infusorian culture was immediately followed by a very noticeable increase in size of the Hydras. In several of the experiments buds were formed during this period of rapid growth. In Experiment 35 (page 195) four large buds developed and separated from the compound polyp 
during the ten days immediately following the introduction of Paramoecia to the aquarium. Two Hydras which I observed for a time began to bud within a few days after the water was stocked with Gastrostylae. It is possible that the excretory products of the Infusoria are favorable for the growth of the Hydras. Vernon showed that the fouling of water by Crabs, Molluses or Holothurians favored the development of Sea-urchin larvae. It is also possible that the Infusoria may prevent the increase of Bacteria harmful to Hydras.

\section{Lateral Grafts.}

Under this head we have three classes of cases to deal with: 1) grafts bearing tentacles; 2) grafts from which the tentacles had been removed, but which regenerated tentacles after the grafting; 3) grafts from which the tentacles had been removed and which did not regenerate tentacles.

For convenience, I shall use the word, sstock «, to desigmate the Hydra into which the graft is set, and »compound « to designate the united graft and stock.

\section{Grafts Bearing Tentacles.}

Experiment 1. - The upper half of a six-tentacled Hydra fusca was grafted into the side of a large seven-tentacled Hydra fusca in the following manner. The Hydra to be grafted was held between the points of fine forceps (under water) and a fine bristle was thrust into the mouth, through the digestive eavity longitudinally, and out through the foot. After the Hydra had become somewhat extended it was cut midway, bristle and all, with scissors, and the head end was then pushed a little farther up the bristle. The stock Hydra was cut half way through transversely and the bristle bearing the half Hydra was pushed into the wound and on through the opposite side of the stock, which meanwhile was supported by the points of forceps applied either side of the place where the bristle was to emerge. The cut aboral surface of the half Hydra was thus pressed into tho break in the side of the stock, and with forceps and needle the Hydras were held in this position for five minutes. After a few minutes more the bristle was pulled out. It should have been left longer, for the pieces partly separated, but they were quickly reunited on being held together with needles. The state of the experiment a half hour after the operation is shown in Fig. $2 a$. The graft was 
firmly united to the stock along the lower (aboral in relation to the stock) surface of the region of contact, although the region of contact between the two pieces was marked by a sharp depression. It was at the upper surface of the wound that the tearing apart occurred in removing the bristle, and here there appeared to be only imperfect contact of the two surfaces. The ectoderm of the stock had become turned in, as shown in the figure, so that here there was really no contact of wounded surfaces. One or two of the tentacles of the graft were injured in the operation.

In this and following experiments is exhibited the high degree of plasticity possessed by the Hydra tissues. The body layers of graft and stock fairly flow together, as if molten. Generally in the course of an hour or two, the graft becomes thoroughly incorporated into the side of the stock, the body layers being continuous and in normal relations. This process went forward rapidly in the case under consideration. The in-turning of the ectoderms between graft and stock (Fig. 2 a) completely vanished. After a few hours it would have been impossible to say which of the oral ends belonged to the foot, had it not been for the difference in the numbers of tentacles. During the first two dass after the operation the compound appeared as in Fig. $2 b$. It was perfectly evident that the two digestive cavities opened into each other. Both trunks expanded and contracted normally and together. The tentacles, however, were not seen to expand. I think this may have been due to low temperature. This compound was kept out of doors for a few days at a temperature not for above the freezing point. The weather becoming colder, the aquarium was brought into the laboratory, after which the tentacles extended normally. On the fourth day (Fig. 2c) it was noticed that the common aboral end appeared to be decreasing in volume, and, although I had no means of determining accurately, it seemed to me that the two trunks above the region of union had increased in length, $-i$. e. there had been a downward progression of the region of union. From the fourth to the eighteenth day this downward migration of the graft continued, although the change from day to day was imperceptible. But if the condition on the eighteenth day (Fig. $2 d$ ) be compared with that on the fourth day (Fig. $2 c$ ), it will be seen that the volume of the common foot-end had considerably decreased. It will be noticed that in Fig. $2 c$ the axis of neither upper part coincides with that of the lower part. In Fig. $2 d$ the axis of the stock is bent but little and that of the graft is nearly 
perpendicular to it, as at the time of grafting. At no time in the history of the compound did the axis of the graft coincide with that of the lower part. Thus, as far as the axes indicated, the lower part was either the common property of the two heads, or of its original owner; it never appeared to belong to the graft. During the period from eighteen to forty-one days after the operation no farther change could be detected. At several observations during: this time the common aboral end was rery much shortened so that the two trunks appeared to arise from the very foot itself. I mistook this at the time for a permanent reduction of the aboral end, but at later observations this end was seen to extend, presenting: the condition shown in Fig. $2 e$, which represents the compound on the thirty-eighth day. It was often noted thereafter that in compounds of this form the common aboral end frequently remained contracted, while the two trunks were fully extended. After a contraction of the whole compound the two trunks generally extended first, and afterwards the lower end. Fig. $2 e$ shows the compound more extended than in the preceding figures. After the forty-first day rapid changes occurred in the lower end. On the forty-sixth day (Fig. 2 $f^{\prime}$ ), when the compound was as fully extended as in Fig. $2 e$, the foot region was very much shortened. By the end of the next three days there was no mistaking the fate of the common aboral end. On the forty-ninth dar (Fig. $2 g$ ) stock and graft presented the appearance of two Hydras (one of six tentacles, the other slightly larger and bearing seren tentacles; united just above their feet, the cross section of the region of union being about equal to that of one of the trunks. A sharp groove separated the two feet. The width of the foot in Fig. $2 f$ would indicate that the original foot had divided to form a foot for each Hydra. Fig. $2 g$ shows the aboral end when the Hydras were fully extended. During the next three days the complete separation of the two Hydras was accomplished. On the fifty-second day (Fig. 2h) the Hydras were found clinging to a thread of alga. Ther adhered to each other by their feet, but the complete separation of the two was perfectly evident. At the place of contact the double laver of foot-ectoderm was very clear. They remained in this condition sexeral days longer. I then carefully pulled them apart, and found that there was indeed no other connection between them than the adhesion of foot to foot.

After persistence of the double-headed form, then, for over seren weeks, there is finally separation resulting in two perfectly normal indiriduals. 
Experiment 2. - The upper half of a seven-tentacled Hydra viridis was grafted into the side of another seven-tentacled polyp by the paraffin method. The position of the graft is seen in Fig. $3 a$, which shows the condition about an hour after the operation. (The broken lines show the relation of the grafted piece to the polyp from which it was cut.) Within a short time all traces of the wound had disappeared. Two days later (Fig. $3 b$ ) slight changes had occurred. The axis of the stock was bent at its intersection with that of the graft. The graft was slightly constricted at its attachment to the stock. On the fourth day (Fig. $3 c$ ) it was found that a protuberance $\left(f^{\prime}\right)$ had appeared at the base of the graft. $A$ needle point pressed against the end of this protuberance adhered strongly to it. There can be no donbt that it was a foot, regenerated by the graft in spite of the complete union of graft to stock. No other change was apparent. On the seventh day (Fig. $3 d$ ) there was no other change than that the regenerated foot was shorter and thicker. It still adhered when a needle was applied to it. During the next three days this regenerated foot completely disappeared. It could not have been functional at any time, as it could not very well come in contact with the surface of the glass, except when the animal was closely contracted. Its disappearance was doubtless similar to tho resorption of abnormally placed tentacles. On the tenth day (Fig. $3 e$ ) the condition was very much like that on the second day (Fig. $3 b$ ), except that the common aboral end had begun to shorten, just as it did in Experiment 1. Lp to this time the axis of the stock had been bent very little, if at all. On the fourteenth day (Fig. $3 f$ ) the aboral end was still more reduced and the axes of the two trunks made very nearly equal angles with that of the aboral end. As the two heads had the same number of tentacles, the graft could be distinguished from the stock only by its smaller size. On the seventeenth day (Fig. $3 g$ ) the graft was seen to be inserted just above the foot of the stock. The graft, at its base, was sharply constricted off from the stock, so that the endoderm connecting the two parts was reduced to a slender thread. On the fourteenth day a few drops of the Paramoecium culture were added to the water and it is certain that both graft and stock grew rapidly during the three following days. The graft grew the faster, becoming by the seventeenth day almost as large as the stock. On the eighteenth day (Fig. $3 h$ ) the aboral ends of graft and stock appeared exactly alike, except that no glandular region could be 
detected at the base of the graft. The attachment of the two Hydras seemed to be by the original foot of the stock. On the twentieth day (Fig. $3 i$ ) there was no mistaking the foot on the graft. It adhered to the glass as firmly as the original foot of the stock. The two Hydras were connected by a thin strand of tissue, mostly ectoderm, but containing a slender thread of green endoderm. They were still united in this way on the next day, but on the twentysecond day they were connected by only a mass of slime and loose material between the feet. They were not disturbed and were again observed on the twenty-third day (Fig. $3 k$ ). The two feet were rounded off in a perfectly normal way. Between them was a small mass of such loose material as is often found clinging to the foot of a Hydra. In the midst of this mass was a slender hyaline thread passing from one foot to the other. It was clearly distinct from the ectoderm and its form would suggest that it was a viscous semi-fluid substance, probably a mass of the foot secretion. A slight pushing of one foot with a needle caused this thread to break and disappear.

Experiment 3. - The upper half of a five-tentacled Hydra viridis was grafted into the side of a six-tentacled polyp of the same species. The hypostome and tentacles of the stock were accidentally injured in the operation, but they quickly regained their former condition. On the second day after the operation the polyp appeared as in Fig. $4 a$. The axis of the stock had become somewhat bent. During the next two weeks there was a slow reduction in the volume of the part of the stock below the graft. Its condition on the twelfth day is shown in Fig. $4 b$. Four days later the reduction of the part below the graft was complete (Fig. 4c). Stock and graft were attached to the glass directly at their union by a common foot. About this time the stock was attacked by a disease, doubtless of a bacterial nature. It became contracted, the two body layers were rough in outline, the endoderm shrunken and the ectoderm much swollen. The tentacles were closely contracted and a bacterial film enshrouded the whole stock. The water was frequently renewed and the bacteria removed at every observation, yet the polyp continued to be infested. On the eighteenth day its condition was so bad that I did not expect to find it again alive. It was cleaned off, however, and, although the film accumulated about it again, it began to improve, so that on the twentieth day (Fig. 4d) it was partly extended. Five of the six tentacles reappeared. The two body layers were still in an abnormal condition. During the next twenty-four hours the body 
resumed nearly its normal appearance and the bacteria did not reappear. The graft remained perfectly healthy during the entire period, and was not even involved in the bacterial film. The graft now began to constrict off from the stock. On the twenty-fifth day (Fig. 4e) there was only a thin rod of endoderm between the two parts. The constriction deepened until the endoderm parted, and on the twenty-ninth day (Fig. $4 f$ ) the Hydras were joined by only a thread of ectoderm. This connecting thread of ectoderm persisted for several days, becoming more attenuated. The stock was again in an abnormal condition. Although well extended, it did not contract in response to violent stimuli, bat remained rigid and motionless. I could not determine that it had formed a foot. On the thirty-third day a mass of loose material held by the secretion of the foot made it impossible to determine whether or not the ectodermal connection still persisted.

Experiment 4. - The oral end of a Hydra viridis, less than half the animal, was grafted into the side of another just above the foot, as seen in Fig. $5 a$, which represents the polyp two hours after the operation. The stock Hydra had six oral tentacles and a short one some distance below the oral ring. The abnormal tentacle was present when the animal was taken from the aquarium. The next day the polyp appeared as in Fig. $5 l$. The part below the graft was much more extended than on the preceding day, and it appeared to me that there had been an actual increase in volume. In grafts of this kind there is a tendency to produce a foot in spite of the perfect welding of graft to stock. This effort often results in the growing out of a considerable mass of tissue at the angle between the graft and the lower part of the stock, the tip of the mass becoming a foot. In this case the foot-forming tendency may have resulted in growth at the base of the graft, causing increase in the volume of both the graft and the part of the stock below the graft, instead of pushing out a new foot. Figure $5 b$ shows that two of the tentacles of the graft, which were injured in the grafting, have united from their bases outward. During the next two weeks the graft increased considerably in size, and at the same time there was an almost imperceptible reduction of the part below the graft. The abnormal tentacle on the stock also shortened slightly. Figure $5 c$ shows the compound on the fourteenth day. Unfortunately four days elapsed before the next observation. On the twenty-first day a single large seven-tentaeled Hydra was found in the Stender dish. This, because 
of its size and number of tentacles, was certainly the stock Hydra. The abnormal tentacle had been completely resorbed. The sudden appearance of a new oral tentacle on a large Hydra is not an unusual thing. No trace of the graft could be found either on the Hydra or in the dish. The changes that had been taking place in the compound indicated that the fate of the graft would have been precisely like that in the first three experiments. Separation in this manner may have occurred, or it is possible that the graft became detached while yet some distance above the foot of the stock, as happened in a later experiment (Experiment 7, page 175). The important thing is, that as far, at least, as one of the Hydras was concerned, the normal condition was regained.

Experiment 5. - The upper half of a six-tentacled Hydra viridis was grafted into the side of an eight-tentacled polyp well down toward the foot. The length of the part below the graft was about equal to the diameter of the trunk (Fig. $6 a$ ). At the end of six days (Fig. $6 \mathrm{~b}$ ) this part had been entirely reduced so that graft and stock rested directly upon a common foot at their junction. This condition persisted for five days, when death ensued.

In two similar experiments of this series death occurred before the fate of the grafts had become apparent.

In two other experiments lateral grafts were inserted at as high a position as possible on the trunk of the stock, - just below the tentacles. Four weeks have passed since the operation. The compounds are at present in a very flourishing condition, both having produced several buds. The water has been kept well supplied with Gastrostylae. Both grafts have migrated about half way from the point of insertion to the foot. One graft has become somewhat constricted at its base, suggesting that it may separate from the stock before it completes its migration to the foot.

As the result of these experiments we may conclude that when the distal end of a Hydra, including the tentacles and about onehalf the trunk, is grafted into the side of another Hydra, the abnormal condition produced is not a permanent one. Regulative processes bring about a return to normal conditions. There eusues in most cases a downward migration of graft upon stock until both arise immediately from the original foot of the stock Hydra. A constriction then appears between graft and stock and a foot is formed at the base of the graft. As the constriction deepens the connection between 
the two polyps becomes drawn out to a slender thread, in which both body layers are present for a time. The thread finally parts leaving two normal Hydras. Sometimes the graft may separate from the stock before it has migrated completely down to the foot. The foot of the graft may arise from the division of the original foot of the stock (Experiment 1), but in most cases the foot of the graft is an entirely new oroan.

\section{Grafts which Regenerated Tentacles.}

Experiment 6. - The aim in this experiment was to graft the lower half of a Hydra viridis into the side of another at a little more than one-third the length of the stock above the aboral end. In order to be sure of getting the graft properly oriented, the whole Hydra was grafted on, a very small piece having been cut from the foot. After a half hour, when the graft had become firmly united, the upper half of the grafted Hydra was eut off. Between one and two days after the operation six tentacles were regenerated on the graft. During the next day a seventh tentacle appeared and the stock, which had originally five tentacles, produced two new ones. During the fifth and sixth days the stock appeared in an unhealthy condition, remaining closely contracted with much thickened ectoderm. It recovered, however, and by the ninth day had regained a normal condition; only six of its seven tentacles. however, reappeared, and it had lost somewhat in volume. The graft by this time had come to be much nearer the foot of the stock than at first. Conditions now seemed to be rery favorable for the Hydras. Both stock and graft increased markedly in size and appeared to be in the best of health. During the next twelve days the part of the stock below the graft was slowly reduced until, on the twenty-first day, the graft was attached directly at the foot of the stock. During the next three days a gradually deepening constrietion formed between stock and graft. The stock retained all of its foot, and a new foot was formed on the base of the graft, where it came in contact with the glass. Two days later, separation had occurred. The seven-tentacled graft was found attached to the bottom of the dish. The six-tentacled stock was attached to a floating filament of alga at about a centimeter's distance from the graft. Both were large vigorous Hydras.

Experiment 7. - The lower half of a Hydra viridis was grafted into the middle of the trunk of another in the manner deseribed in the last experiment. Immediately after the union had 
been made the connection was very slender (Fig. 7a). Two hours later (Fig. $7 b$ ) the connection had increased greatly in diameter. Twenty-nine hours after the operation (Fig. $7 c$ ) the graft bore several tentacle buds and at its base a foot $\left(f^{\prime}\right)$ had budded out. This foot was not found attached to the glass; it could hardly hare become attached except by the bending over of the stock. It adbered verystrongly to a needle point. On the third day (Fig. $7 d$ ) the graft bore four tentacles. A young bud had appeared on the trunk of the stock, a little below the graft and opposite it. During the next three days this bud developed and became detached. The graft produced a fifth tentacle, and the connection between graft and stock became slightly longer and thinner. There had also been some downward migration of graft on stock. On the seventh day (Fig. 7e) both Hydras were found attached side by side. The foot of the graft was brought down to the glass partly by the leaning over of the stock and partly by the stretching downward of the connection between stock and graft. During the next four days the compound was always found attached in this way, except upon one occasion, when the graft was not attached. The connection was evidently under some tension when both feet were attached. It gradually became thinner until the endoderm could hardly be distinguished at its center. On the thirteenth day the two Hydras were found to have separated. The graft was attached at a centimeter's distance from the stock. A slight swelling on the ectoderm of each (Figs. $7 f^{\prime}$ and $7 f^{\prime \prime}$ ) was the only eridence of their former connection. Both were normal vigorous Hrdras.

Experiment 8. - A quarter of a Hydra viridis cut from the upper part of the trunk was grafted into the middle of the trunk of a seven-tentacled polyp. The relation of the graft to the Hydra from which it was taken is shown by the broken lines in Fig. $8 a$. The upper half of the Hydra was first grafted on, and, after the graft had firmly united, its distal half was cut off. Twenty-seren hours later (Fig. $8 b$ ) the graft was somewhat constricted toward its base and there were signs of tentacles. On the third day (Fig. $8 \mathrm{c}$ ) the graft bore four tentacles and was less narrowed toward the base. On the fifth day it became noticeable that the body of the graft was decreasing in volume. By the seventh day (Fig. $8 d$ ) it was markedly smaller. On the tenth day (Fig. $8 e$ ) the hypostome of the graft arose almost directly from the trunk of the stock and the connection was very slender. Yet the four tentacles of the graft remained fully as 
large as those of the stock, which was a very large and vigorous Hydra. There was no noticeable change during the next three weeks. On the thirty-sixth day (Fig. $8 f$ ) the connection of the endoderms of graft and stock was doubtful. The hypostome was smaller and of abnormal shape. During the sixth week bacteria, evidently, caused the disintegration of the graft as well as of the "head " of the stock.

It is evident from Experiments $6-8$ that pieces lacking tentacles and grafted by their aboral ends into the side of a Hydra may regenerate a number of tentacles. In two cases, regulative processes resulted in the separation of graft from stock. In one case all but the hypostome and tentacles of the graft was resorbed. The constriction at the base of the persisting part (Fig. $8 e$ ) indicated a tendency to separate from the stock, but the fate of the graft was undetermined.

The separation of the graft took place in one case (Experiment 6) exactly as in the first series of experiments, - by the migration of the graft to the foot of the stock, where the two Hydras were constricted off from each other. In Experiment 7 the graft formed a foot before the downward migration had progressed far, and there followed a gradual attenuation and final rupture of the strand connecting the two polyps. The behavior of the graft in Experiment 8 may be better understood after noting the results of some following experiments.

3. Grafts which did not Regenerate Tentacles.

Experiment 9. - The lower half of a Hydra viridis was grafted into the middle of a seven-tentacled polyp, as shown in Figure $9 a$. Two days later the compound appeared as in Figure $9 b$. The graft formed a large conical elevation on the side of the stock. At the point $i$ of Figure $9 b$, what I took for a bit of transparent ectoderm extended into the endoderm. By the fourth day (Fig. 9c) the conical elevation had been much reduced. The indentation of the endoderm (i) was still visible. On the sixth day (Fig. 9d) there was no conspicuous abnormality on the Hydra. The ectoderm was slightly thicker where the graft had been resorbed, and, strange to say, the minute indentation of the endoderm still persisted. This mar hare been caused by some foreign matter - a bit of paraffin, possibly - introduced into the tissues during the grafting. 
In the preceding experiments, except Experiment 8, the regulative processes resulted in the separation of graft and stock to form two normal Hydras. In this last experiment (9) the regulation of the abnormality on the stock resulted in the loss of the individnality of the graft, which was completely incorporated into the bods of the stock. A normal form was regained by the stock at the expense of the graft.

4. Factors which Determine the Fate of Grafts.

This process of regulation by resorption was observed in several other experiments similar to that last described. The problem therefore presented itself of ascertaining what are some of the conditions which determine whether the graft shall produce tentacles and finally separate from the stock, or whether it shall be resorbed by the stock. In previous experiments on regeneration in Hydra (RAND, 1899) it was fonnd that large pieces produced more tentacles than small ones. Is the size of the graft a factor in determining whether it shall be resorbed, or produce tentacles and separate from the stock? It was also thought possible that the graft might suffer one or the other fate according as it was cut from the lower or upper regions of the trunk. Some experiments were made in which halves and quarters of Hydras from both lower and upper regions of the trunk were used as grafts.

a. Pieces from the Lower Part of the Trunk.

In these experiments the foot was first cut away, as little as possible of the end of the trunk being removed. A second cut was then made (generally after grafting, to be sure of the orientation) so as to obtain approximately one-half or one-fourth of the trunk. In all the quarter grafts the lowest quarter, that nearest the foot, was used.

Experiment 10. - A lower piece, slightly less than one-half the trunk, was grafted upon a five-tentacled Hỵdra viridis near the foot. At first I could see no connection between the endoderms of graft and stock (Fig. 10b). After three hours (Fig. 10a) the endoderms were continuous. After two days (Fig. 10r) there were no signs of tentacles. By the sixth day (Fig. 10d) the graft was considerably less in rolume. Two tentacles on the stock had united from base outward. On the eleventh day (Fig. 10e) the graft was no large: than a contraeted tentacle. This small protuberance was 
very slowly resorbed. On the twenty-sixth day (Fig. 10f) the point at which the resorption had occurred conld scarcely be discovered.

Experiment 11. - A lower half was grafted as shown in Figure $11 a$. No signs of tentacles appeared on the graft after several days. The end became rounded off and the ectoderm at the tip became much thicker than at any other region of graft or stock. The endoderm of the graft was of a darker green than that of the stock and was darker toward the end than toward the base. This thickening of the ectoderm at the tip of the graft and the darker color of the graft were found to be characteristic of pieces undergoing resorption, especially during the earlier stages of the process. No change in the volume of the graft could be detected during the first two weeks. On the seventeenth day I thought it was slightly smaller (Fig. $11 b$ ). On the twentieth day (Fig. $11 c$ ) there was no mistaking the decrease in size. For the first time since the operation the graft was well stretched out and was no longer darker colored. The graft continued to decrease slowly. On the thirty-seventh day it was as in Figure $11 d$. Four days later (Fig. 11e) a very inconspicuous prominence marked the position of the graft. On the fortythird day no trace of it could be seen. This stock was an unusually large and vigorous animal. It was well supplied with food and was seen to take food. On the twentieth day, the body was greatly distended. The polyp increased in size very noticeably during the resorption of the graft and appeared to be in the very best of condition at the end of the forty-three days.

Experiment 12. - A lower half was grafted a little above the middle of the trunk of a seren-tentacled Hydra viridis. In sixteen hours a foot had formed exactly as in Experiment 7 (page 175), the graft appearing like that of Figure $7 c$ except that it bore no tentacle buds. At the end of two days six tentacles were well grown and the compound was attached to the glass by both feet. As in Experiment 7, the foot of the graft was brought down to the glass partly by the bending orer of the stock and partly by the downward stretching of the connection. During the next eight days the connection between graft and stock became lower on the trunk of the stock; it also became longer and thinner. From the tenth to the twenty-third day no marked change in form took place. During the latter part of this period the compound became unhealthy. Althongh food was provided, both parts decreased in size. On one occasion the stock was seen to discharge from the mouth a large 
mass of loose green material, apparently degenerated endoderm. At the end of the fourth week the compound could not have been onehalf its original size. During this dwindling in volume the form did not change, except that the foot of the graft projected less prominently. On the thirty-sixth day the endoderm had vanished from the slender connection and a day later the two polyps appeared quite separate although still in contact. They were not disturbed and five day's later were found some distance apart. They had increased a little in size, perhaps, and seemed in fairly good condition.

Experiment 13. - A lower piece from a six-tentacled Hydra viridis, and somewhat greater than one-fourth the volume of the trunk, was grafted into the side of a seven-tentacled $H$. viridis a little below the middle. By the third day a number of tentacle buds had developed and the graft was a little lower on the stock. During the next day the compound died.

Experiment 14. - A lower piece considerably greater than one-fourth the volume of the trunk was grafted into the side of an eight-tentacled Hydra viridis about one-fourth its length above the foot. By the third day the graft had regenerated several tentacles. The compound died at the end of a week.

Experiment 15. - The lowest quarter of a Hydra riridis was grafted into the trunk of another a little below the middle. The stock bore a testis $(t)$ near the tentacles (Fig. 12a). On the next day (Fig. $12 b$ ) the graft was well extended and between it and the testis was visible the thickening whifh marks the beginning of an ovary. On the second day I was much surprised to find that the outer tip of the graft adhered very strongly to a needle; it had, in fact, formed a foot. Is this a case of reversed polarity? There could have been no mistake about the orientation of the graft, for a Hydra minus only its foot was united to the stock and the upper three-fourths of the graft was cut away an hour after. From the third day on, the compound was found attached by both feet. The ovary developed rapidly. Figure $12 c$ shows the condition on the eight day. Two days later (Fig. 12d) the egro was completely rounded off and it separated from the basal plate during the next day. The basal plate disappeared in four or five days, and at the same time the graft came to lie nearer the foot of the stock and decreased in volume. On the twentieth day it appeared as in Figure 12e. For a few days after the casting off of the egg, the Hydra did not extend fully and the tentacles almost disappeared. It soon recovered a 
perfectly normal condition, but only five tentacles came out. Little change occurred during the fourth week and the animal died during the following week.

This graft was being resorbed in spite of its having formed a foot at its tip. In a later experiment, which resulted in a similar condition (Experiment 39, page 201), such a supernumerary foot was completely resorbed.

Experiment 16. - The lowest quarter of a Hydra viridis was grafted to another a little above the middle of its trunk. On the second day the end of the graft was rounded off and the ectoderm at its tip was twice as thick as elsewhere. The endoderm was darker green than that of the stock. On the third day the decrease in volume of the graft could be detected. The reduction of the graft continued in a manner precisely like that of Experiment 9 (page 177) and the process was practically completed at the end of a week. At that time the Hydra was not conspicuously abnormal when extended. When contracted, the position of the graft was marked by a low swelling on one side of the trunk.

\section{b. Pieces from the Upper Part of the Trunk.}

In these experiments - all upon Hydra viridis - the upper half of one Hydra was grafted upon the trunk of another and, when well united, the half-Hydra was cut across just below the tentacles or at the middle, according as a half or a quarter Hydra was desired for a graft.

Experiment 17. - An upper piece, rather less than one-half the volume of the Hydra, was grafted into the middle of the trunk of another. On the second day the graft bore four tentacles and on the fourth day six tentacles. On the tenth day the beginning of the downward migration of the graft was detected. The final fate of the graft was not determined.

Experiment 18. - An upper half was grafted into the trunk of a six-tentacled Hydra a little below the middle. On the second day the graft bore two tentacles and on the fourth day four tentacles. By the tenth day the graft had moved some distance down the trunk of the stock. The compound died while the graft was yet a short distance above the foot of the stock.

Experiment 19. - The upper half of a nine-tentacled Hydra was grafted into the middle of a six-tentacled polyp (Fig. 13 ( ). Twentyone hours later (Fig. 13b) a foot $\left(f^{\prime}\right)$ had grown out near the base of the graft. On the second day the graft bore three tentacles; on 
the fourth day (Fig. 13c) it had five tentacles and it was then evident that the graft had begun its migration down the trunk of the stock. This change of position continned slowly up to the eighteenth day, when the foot of the stock was reached. The foot- of the graft was found attached for the first time on the tenth day. Figure $13 d$ shows the condition on the fifteenth day. On the twenty-third day (Fig. 13e) only a slender thread connected the two trunks. Three days later the two Hydras were found attached at a considerable distance from each other. Both stock and graft were very large and in fine condition throughout the experiment.

Experiment 20. - An upper quarter grafted into the middle of a nine-tentacled stock regenerated six tentacles in four days. At the end of a week the downward migration of the graft was detected. Between the twelfth and the nineteenth days an ovary developed on the stock and the egg was cast off. Between the twenty-second and twenty-fifth days a bud developed and separated from the stock. At the end of the fourth week the arfuarium water became too foul and the compound died.

Experiment 21. - An upper piece from a seven-tentacled Hydra, a little more than one-fourth the trunk, was grafted into the side of a seven-tentacled Hydra at one-third the length above the foot (Fig. 14a). On the second day the graft bore four tentacles. On the fifth day (Fig. 14b) the axes of the two oral portions were symmetrical with respect to that of the foot end. This condition persisted for five or six days. On the fourteenth day a remarkable change appeared in the relation of the axes. The axis of the graft coincided with that of the common foot end. The compound seemed to be a four-tentacled stock bearing a seven-tentacled graft. Figure $14 c^{\prime}$ shows the compound on the nineteenth day. The foot $(f)$ originally belonged, not to $g$, as would appear, but to $s$. It must further be noticed that the stock was narrowly constricted just above its junction with the graft. This condition of the axes was not a temporary one, accidental at the time of observation. The compound, having been made to contract and allowed to expand several times, showed no change in the relation of the axes. When contracted (Fig. 14c) it was even more erident that the graft had appropriated the foot of the stock. There was no change up to the twenty-fourth day. The fate of this compound was the separation of the upper part of the stock from its own foot end, which was left upon the sraft. This occurred at the end of the fourth week. 
Experiment 22. - An upper piece, a little less than one-fourth the trunk, was grafted into a nine-tentacled Hydra just above the middle. On the next day the graft presented the characteristic appearance of a piece being resorbed. It was of a darker green than the stock and the ectoderm at its free end was much thickened. At the end of ten days the resorption was practically completed. Only when the polyp was closely contracted could a slight swelling be detected in the region of the graft.

Experiment 23. - An upper piece a little larger than onefourth the trunk was grafted into the side of a six-tentacled Hydra just below the middle (Fig. $15 a$. Figure $15 b$ shows the compound on the fifth day. The graft was of a darker green than the stock and the ectoderm at its tip was thickened. From this time on the graft slowly decreased in volume. By the eighteenth day (Fig. 15 c) it had become merely a swelling on the side of the stock, causing a bend in the axis of the stock. On the next day only a thickening of the ectoderm and a slight bend in the axis of the stock marked the position of the graft.

The following table presents the results of Experiments 6-23.

\begin{tabular}{|c|c|c|c|c|c|c|c|}
\hline \multicolumn{4}{|c|}{ An upper piece grafted } & \multicolumn{4}{|c|}{ A lower piece grafted } \\
\hline \multicolumn{2}{|c|}{ Regenerated tentacles } & \multicolumn{2}{|c|}{$\begin{array}{c}\text { Resorbed } \\
\text { (notentacles regenert'd) }\end{array}$} & \multicolumn{2}{|c|}{ Regenerated tentacles } & \multicolumn{2}{|c|}{$\begin{array}{c}\text { Resorbed } \\
\text { (no tentacles regenert'd') }\end{array}$} \\
\hline $\begin{array}{c}\text { Number of } \\
\text { Experiment }\end{array}$ & $\begin{array}{c}\text { Size } \\
\text { of piece }\end{array}$ & $\begin{array}{l}\text { Number of } \\
\text { Experiment }\end{array}$ & $\begin{array}{l}\text { Size } \\
\text { of piece }\end{array}$ & $\begin{array}{l}\text { Number of } \\
\text { Experiment }\end{array}$ & $\begin{array}{c}\text { Size } \\
\text { of piece }\end{array}$ & $\begin{array}{l}\text { Number of } \\
\text { Experiment }\end{array}$ & $\begin{array}{c}\text { Size } \\
\text { of piece }\end{array}$ \\
\hline 18 & $1 / 2$ & & & 6 & $1 / 2$ & 9 & $1 / 2$ \\
\hline 19 & $1 / 2$ & & & $\tau$ & $1 / 2$ & 11 & $1 / 2$ \\
\hline 17 & $1 / 2-$ & & & 12 & $1 / 2$ & 10 & $1: 2-$ \\
\hline 21 & $1 / 4+$ & 23 & $1 / 4+$ & 13 & $1 / 4+$ & 15 & $1 / 4$ \\
\hline 8 & $1 / 4$ & 22 & $1 / 4-$ & 14 & $1 / 4+$ & 16 & $1 / 4$ \\
\hline 20 & $1 / 4$ & & & & & & \\
\hline
\end{tabular}

Each fraction indicates the size of the piece grafted in terms of the whole Hydra from which it was cut. The plus or minus sign indicates that the piece was somewhat larger or smaller than the half or quarter.

of the nine half-Hydras grafted, six regenerated tentacles and three were resorbed. Of the nine quarter Hydras disregarding the plus and minus signs), five regenerated tentacles and four were resorbed. If the signs be regarded the results are more significant, 
for three of the five $»$ quarters s that regenerated were really greater than quarters, and the piece which was less than a quarter was resorbed.

This shows, I believe, that the larger grafts have the greater capacity for the regeneration of tentacles.

Comparing the upper and lower pieces, the difference in the fate of the halves is rather marked. While the upper halves all regenerated tentacles, only $50 \%$ of the lower halves did so. Upper and lower quarters show little difference in behavior.

\section{The Regulation of Lateral Grafts.}

Twenty-three experiments have been described in which alnormal forms were produced by grafting a piece of one Hydra into the side of another. In all cases, where death did not occur while the experiment was in progress, regulative processes brought about a return to normal conditions. In most of the cases where the compounds died while under observation, changes had taken place indicating that the grafts would ultimately have separated from the stocks. The results of the foregoing experiments justify the conclusion that no lateral grafts, in Hydra viridis, will persist as permanent abnormalities.

The regulation of the abnormalities takes place by two different methods: 1) the separation of graft and stock to form two perfectly normal Hydras; 2) the resorption of graft by stock, the stock regaining a normal form at the expense of the graft.

If the graft bears tentacles when grafted, or if it regenerates tentacles after the operation, it is destined to separate from the stock. If a piece without tentacles is grafted and if it does not regenerate tentacles, it is destined to be resorbed. It appears, then, that the fate of the graft depends upon its degree of specialization. An indifferent piece bearing none of the oral or aboral organs of a normal polyp is completely resorbed by the stock. A graft bearing a hypostome and tentacles maintains its individuality and eventually becomes a free normal polyp.

In Experiment 8 (page 176) the apparent exception to these rules may be explained as due to a conflict between the two tendencies. For some reason, the resorption of the graft began in spite of the fact that it had a hypostome and tentacles. But when the resorption of the trunk of the graft had progressed so far that its hypostome and tentacles arose almost directly from the trunk of the stock, the 
tendency to persist, which is exhibited by the specialized oral parts, asserted itself, and for nearly five weeks the remnant of the graft hung on the side of the stock without undersoing much change. It could resist resorption, yet it did not possess the power of accomplishing its own separation, though the constriction at the base of the remuant indicated the tendency toward separation. It is more than probable that, had the animal lived, the graft must finally have separated, or else have disappeared by the rery slow dwindling away which was going on.

The resorption of whole buds, including the hypostome and tentacles, has been described by Kleinenberg (1872) and by Marshall (1882). Kuennenberg mentions an individual of "Hydra aurantiaca " which bore buds of several generations. The colony was kept without food. Few of the buds came off and several were completely resorbed. The body of the bud decreased until the hypostome sat directly upon the trunk of the parent, the tentacles remaining of normal length. Then the tentacles were gradually shortened until only a small lump represented the bud. This finally disappeared. I doubt if such resorption of buds ever occurs in Hydra viridis. The buds derelop. so rapidly that the effects of lack of food could hardly be felt in time to prevent the maturing of the bud.

It was shown that larger grafts tend to regenerate tentacles, while smaller pieces tend to be resorbed. The graft of Experiment 8 was a quarter of a rather small Hydra and was considerably less than one-fourth the rolume of the stock. We may suppose that its size placed it at the critical point as regards the two fates. Both tendencies asserted themselves in the graft at once, and the fate of the graft was the result of the conflict of the two.

If the graft possesses a foot, but not the oral organs, its fate is resorption in spite of the specialization of the foot (Experiment 15, page 180. Also in Experiment 39, page 201, the resorption of a graft bearing a foot occurred). Yet the resorption of a foot, especially if the organ is functional, - that is, if the compound is attached by means of it, - appears to be a more difficult matter than the resorption of an equally large piece not bearing a foot. In Experiment 15 (Figs. 12a-e) the graft persisted nearly four weeks and was still of considerable volume when death occurred. In other experiments, grafts as large or larger were resorbed in much less time. 
The results of the experiments tabulated on page 153 show that the size of grafts from which the tentacles have been removed is a factor, and probably the most important one, in determining the fate of the graft. Larger pieces regenerate tentacles and separate from the stock; smaller pieces are resorbed. It has been shown by Miss Peebles (159i) and others that pieces of Hydra viridis very much smaller than auy I used as grafts are perfectly capable of regenerating hypostome and tentacles, becoming perfect polyps. In these cases of resorption, then, the operation of grafting must have exerted some disturbing influence upon the tissues of the graft, preventing the piece from regenerating as it would have done if it had not been grafted.

Experiment 11 (page 179) is another illustration of conflicting tendencies in the graft. This graft was the largest piece that was resorbed in all of my experiments. It was larger than many pieces that regenerated. Yet the disturbances caused by grafting inhibited the producing of tentacles. On the other hand, its large size prevented it from being immediately resorbed. For two weeks no change could be detected in its rolume and six weeks were required for its complete resorption.

It is quite probable that pieces from the upper part of the trunk are more likely to regenerate tentacles than pieces of the same size from the lower part. In my work on the regeneration of tentacles (RAND, 1899) the lower halves of Hydras were found to regenerate more tentacles, on the average, than did the upper halces. That the probability of the regeneration of tentacles should be greater in upper pieces than in lower pieces, under circumstances where the regeneration is attended with unusual difficulty, as it certainly is in grafts, does not necessarily conflict with the capacity of lower pieces for producing a greater number of tentacles, for the ability to regenerate tentacles is not necessarily correlated with the capacity for the production of a large number of tentacles. It is quite to be expected that the tissues in the region just beneath the tentacles should possess a greater capacity for regeneration of tentacles than tissues in the lower part of the trunk.

The failure of large grafts to regenerate must be due to disturbances caused by the grafting operation. Large pieces, when grafted, regenerate more readily than small pieces, because the greater mass of tissue is relatively less affected by these disturbances. The precise 
nature of the changes effected in the graft can only be surmised. The operation may cause a disturbance of that quality of the tissues which is termed »polarity . It is well known that the oral end of a piece of Hydra trunk will regenerate only tentacles, while an aboral cut surface will produce only a foot. I know of no eases of the reversal of this law except in the case of grafts or pieces which have been snbjected to some operation other than simple cutting. Whatever this $»$ polarity" is, its manifestations are perfectly definite. If the tissues are subjected to the stimulus which proceeds from an oral cut surface, the oral parts are regenerated. If the same tissues are stimulated from the opposite direction by an aboral cut surface, a foot is produced. Whether these phenomena are to be explained by supposing that the histological elements of the tissues possess something analogous to magnetic polarity, each cell having its „positive and negative poles", as has been proposed by Nussbaci and others, or whether, as is suggested by Dr. Davenport, they can be explained by means of protoplasmic currents which maintain constant and definite directions in the tissues, - whaterer "polarity" is, it appears that the operation of grafting may involve the neutralization or even the reversal of it in the graft within a certain distance of the plane of union. This effect of the grafting is probably connected with the flowing together of the tissues of stock and graft. All of the experiments showed the remarkalle plasticity of the tissues. The adhesion of a few cells at the beginning of the operation was sufficient to ensure the complete welding together of graft and stock in the course of a few hours. The process is best described by saying that graft and stock flow together like molten masses. It is likely that the tissues of the graft, so far as they are concerned in this flowing, suffer disturbances of ppolarity \&. This would serve to explain the difference in the behavior of large and small pieces. In a large graft the polarity of only a relatively small region near its base is affected. The distal part of the piece is undisturbed and regenerates normally. In a small graft the polarity of the entire mass may be affected, inhibiting the regeneration of tentacles.

The shape of a graft, as well as its size, influences its fate to some extent. I find that grafts which are short and of large diameter are more apt to be resorbed than pieces of the same volume which are longer and of less diameter. The greater length of the graft leaves more of it free from the disturbing effects of the operation. 
That there may be eren a reversal of polarity, by grafting, is shown by Wetzel (1895, page 285, Versuch rom 24. November). My Experiment 15 (page 180) is best explained as such a case.

\section{a. Separation of Graft and Stock.}

The usual manner of separation of the tentacled graft and stock involved the slow migration of the graft down the trunk to the foot of the stock. A constriction then appeared at the base of the graft and the connection was drawn out to a more and more slender thread, which finally ruptured. The foot of the graft was either a part of the original foot of the stock (Experiment 1) or a new foot developed upon the graft (Experiments 2,3 and others). Sometimes a foot was formed at the base of the graft soon after the operation (Experiment 19) and persisted during the downward migration of the graft, remaining as the foot of the separated graft. In Experiment 2 such a foot was formed but was resorbed during the downward migration of the graft, necessitating the fornation of a second new foot on the graft at the time of separation. In some cases the graft came off before it had migrated to the foot of the stock. This occurred in cases where a foot had already been formed at the base of the graft, and also where no such foot had been formed.

The migration of the graft down the stock was not confined to such grafts as finally separated from the stock. It occurred also in cases of resorption where the process extended over a long period. Experiment 11 affords a conspicuous example. In this case, however, the downward migration was entirely completed before any decrease in the volume of the graft was detected. My experiments thus far have not enabled me to determine whether or not migration and resorption may go on simultaneously. A period of several days, or even two weeks, elapsed before the beginning of the downward migration could be detected.

It is possible that the migration of the graft is to be explained as a purely mechanical effect of gravity. The much-vacuolated cells of the Hydra form very watery tissues, which must yield readily to tension or pressure. The specific gravity of Hydra has been found by Willians (1S99) to be 1.0095 . The weight of the graft is supported at the junction of graft and stock. This weight may be sufficient to cause the cells of the graft to slowly sink downward through those of the stock. My Hydras were generally found attached vertically to the bottom of the dish. That the very small, partly 
resorbed, graft of Experiment 8 did not sink noticeably does not conflict with this explanation. A simple experiment, which I shall try, would settle the question. If a Hydra bearing a large lateral graft could be made to remain attached to the under surfaee of some object for a few weeks, the direction of migration of the graft would be conclusive for or against this explanation. If this be the true explanation, the downward migration of the graft must be excluded from the true regulative processes. These would then include only the constricting off of the graft from the stock. The fact that a graft may separate while yet some distance above the foot of the stock shows that the constricting does not necessarily occur at the foot of the stock. Yet the separation appears to occur there most readily, for while the migration to the foot occupied very different periods of time in the several experiments, the constricting off of the graft, with few exceptions, did not begin until it had reached the foot of the stock.

It is important to notice that the fate of the graft is independent of the condition of the compound. In Experiment 2, separation occurred when the compound was well fed and, to all appearances, a perfectly healthy polyp. In Experiment 7, the derelopment of a bud while the graft was attached proves the vigorous condition of the stock. In an experiment to be described later (Experiment 35, page 195) both graft and stock bore buds at the same time and four in all were given off. In Experiments 3 and 12 the compounds were in very poor condition. Both graft and stock decreased considerably in volume during the experiment. Yet they separated just as the others did, except that the latter part of the process progressed somewhat more slowly. Resorption occurred when the stock was very large and well supplied with food and also when it was not fed. The regulation of abnormalities appears not to depend upon the condition of nutrition in the organism; it is a morphological necessity.

\section{Historical.}

Trenblex (1744) described a case of regulation similar to that of Experiment 1. He found a double-headed bud still attached to the parent. It became detached and in the course of two months the region of union of the two trunks mored aborally until they arose from a common foot. The animal died in this condition. Hydras placed one within another separated to become two normal 
polyps. But when the inner polyp was everted, no separation occurred. Trembley demonstrated the possibility of grafting.

BAKER (1744) was unsucessful in his attempts at grafting.

Marshall (1882) got the surfaces of a fresh cut to reunite. He took a Hydra bearing a bud and cat across the trunk of the parent midway between the base of the bud and the head of the parent. The axis of the bud swung about into line with that of the lower part of the parent and the bud remained permanently as the head of the parent. The part of the parental trunk above the bud regenerated tentacles and separated from the rest of the animal. This resembles my Experiment 21, where a graft replaced the upper part of the stock.

WeTzeL (1895) grafted two Hydras together end to end, the aboral end of one, from which the foot had been cut, being attached to the oral end of the other, from which the head had been cut. The cut surface of the latter, the proximal part of the compound, was not entirely covered by the end of the former. The uncorered part of the oral surface of the proximal part regenerated a head. The distal Hydra migrated down the trunk of the proximal Hydra to its budding zone. Here the account of the experiment ends. Two Hydras joined by like ends, either oral or aboral, separated to become normal polyps. Two upper halves, united by the aboral surfaces, became a single polyp. The axis of the compound bent at the plane of union so as to tend to bring the two trunks parallel to each other. The two trunks united, the union progressing from the proximal toward the distal ends. The union of the two heads brought together a number of tentacles abnormally great for a single polyp. The number was reduced-by the uniting of adjacent tentacles from the base outwards. WeTzEL worked on Hydra fusca.

\section{The Behavior of Buds and Grafts Compared.}

Werzel (1895, page 288; finds that the separation of graft and stock takes place through »eine Reihe von Processen, die sich auf das deutlichste als Knospung darstellen". Yet the manner of separation of the graft is very different from that of a bud. A piece can be grafted into the budding region of a Hydra so as to resemble very closely a bud. Figures $8 a, 8 b$ and $8 c$ might well represent stages in the development of a bud. The graft in Figure $8 c$ was as large as some buds at the time of separation, yet it remained attached. 
A bud of Hydra viridis generally comes off within two or three days after its first appearance. The constriction at its base begins to form as soon as the tentacles bud out. The constriction deepens very rapidly and the bud may come off in less than twenty-four hours after the beginning of the constriction. According to some observers the bud's tentacles become attached to some object and a sudden contraction of the bud tears it loose.

Most of my grafts were inserted in the budding zone of the stock. Such grafts very soon come to differ from buds in several ways. The long axis of a bud is generally perpendicular to that of the parent and the axis of the parent is bent very slightly, if at all, at the base of the bud. A lateral graft, after a day or two, canses a bend in the axis of the stock, resulting in a Y-shaped form. The trunk of a bud which has not yet begun to constrict off arises somewhat sharply and abruptly from that of the parent. A graft, at its base, swells out and curres into the trunk of the stock. Even if a bud should tend to migrate down the trunk of the parent, the amount of mration would not be noticeable in the short time during which it remains attached. The most marked difference between bud and graft is in the progress of the constriction. In the case of a graft, weeks generally elapse before the beginning of a constriction and then it deepens so slowly that many dars are required for the complete separation.

Some experiments were made upon budding Hydras to throw light, if possible, upon the nature of the differences between the behavior of buds and grafts. Sereral questions suggested themselves. Can the separation of the bud be delayed by injuring the parent? Will an injury at the base of the bud delay or prevent the separation? Is it the grafting process that renders a graft incapable of separating readily from the stock? If a bud be severed from the parent and grafted back on to the parent, will its subsequent fate be that of a bud or of a graft?

Experiment 24. - A nine-tentacled Hydra viridis bore a large seren-tentacled bud, which was still firmly united to the parent, although the digestive cavities were no longer connected. The trunk of the parent was divided into three pieces by two cross cuts, one just above and one just below the base of the bud, leaving a short cylindrical piece of the parent attached to the bud (Fig. 16). On the third day after the operation the bud was found detached from the parent piece, which had regenerated five tentacles. 
Experiment 25. - A seven-tentacled Hydra riridis was taken bearing a large bud which was not yet constricted off at its base. The parent was cut (Fig. 17 a) as described in Experiment 24. $\mathrm{By}$ the next day (Fig. 17b) a constriction had formed so as almost to separate the endoderms of bud and parent. On the second day the bud was found detached from the parent piece. On the fourth day the parent piece bore three tentacles.

Experiment 26. - An eight-tentacled Hrdra fusca bore a large six-tentacled bud, which was united to the parent by the ectoderm only. The parent was cut as in the preceding experiments Fig. 18a). On the third day thereafter (Fig. 18b) the bud was entirely separated from the parent piece, although it still adhered slightly.

Experiment 27. - A six-tentacled Hydra fusea bore a young bud upon which the tentacles had not yet appeared. The parent was cut as in the preceding experiments (Fig. 19a). By the third day (Fig. $19 b$ ) the bud had produced six tentacles and the constriction at its base had progressed so far as to sever the endoderm. On the fifth day (Fig. 19c) the bud only adhered to the parent piece.

Experiment 28. - A nine-tentacled Hydra viridis bearing a bud much younger than any used in the preceding experiments was cut across above and below the bud. Figure 20 shows the piece bearing the bud one-half hour after the cutting. The bud developed rapidly, producing five tentacles. On the second day after the operation it had detached itself from the parent piece. The parent piece was attached by a new foot and bore the bud of a tentacle.

Experiment 29. - A large seven-tentacled Hydra viridis was found bearing two buds, one being very young, the other, opposite it, about ready to be detached. Cuts were made as indicated by the broken lines in Figure $21 a$. Ten minutes later the piece bearing the buds appeared as in Figure $21 b$. During the next twenty hours the older bud became detached, while the younger one grew rapidly and produced four tentacles (Fig. $21 \mathrm{c}$ ). At this time a second operation was made for the purpose of injuring the base of the bud. An attempt was made to eut across the parent piece so as to remove a slice from the base of the bud. At the first touch of the scalpel the parent piece contracted to a sphere and I was unable to determine in what direction the cut was made across the parent piece. Judging from the size of the piece left attached to the bud, it is probable that the cut took the direction of the broken line in $\mathrm{Fi}$ gure 21c. Howerer this may hare been, I succeeded in cutting 
away part of the base of the bud, leaving the rest of the connection between bud and parent uninjured. Figure $21 d$ shows the condition three hours after this second operation. The ectoderm and endoderm on one side of the bud were continuous with the corresponding layers of the parent. On the opposite side, the ectoderm was interrupted at the base of the bud and a small mass of endoderm $\langle e\rangle$ protruded from the break. Twenty-four hours after the second operation (Fig. 21e) all traces of the wound had vanished; the bud had developed a foot at $f^{\prime}$ and was becoming constricted off from the parent piece. The constriction deepened during the next day, and on the third day the separation was complete (Fig. 21f). A light touch detached the bud.

In the following five experiments (Nos. 30-34) a more serious injury was inflicted upon the bud by splitting it for its entire length, the same eut being prolonged to divide the trunk of the parent transversely.

Experiment 30. - An eight-tentacled Hydra viridis bearing a young bud was cut as shown by the broken line in Figure $22 a$. In the course of a few hours the edges of each part of the split bud came together, so as to restore the cylindrical form of the bud, and at the same time the half-bud swung around so as to assist in closing the cut end of the parent. Twenty-four hours after the operation the lower part of the polyp appeared as in Figure $22 b^{\prime}$, and the upper part as in Figure $22 b^{\prime \prime}$. Both half-buds had increased greatly in size and had produced tentacles. The upper parent piece had formed a foot $\left(f^{\prime}\right)$, and the base of the bud was sharply constricted. The axis of the lower half-bud coincided with that of the parent piece, and only a slight constriction appeared between the two parts. On the second day the upper half-bud was detached. The constriction between the lower half-bud and parent was a little deeper. On the third day (Fig. 22c) the lower half-bud was almost separated from the parent piece, and had formed a foot $\left(f^{\prime}\right)$ at one side of the point of connection. On the fifth day the bud was detached and the parent piece bore several buds of tentacles. The bud probably became detached on the fourth day (a Sunday), when no observation could be made.

Experiment 31. - An eight-tentacled Hydra viridis bearing a large bud was cut as in the preceding experiment. The connection of bud and parent was so small that the lower piece of the bud was torn from the parent piece in the cutting. It was clearly seen, 
however, that the cut laid open the cavity of the upper piece of the bud for its entire length including its connection with the parent. Four of the six tentacles were on the upper piece of the bud. The history of the apper half-parent with its fragment of bud differed in no important way from that of the similar piece in the preceding experiment. The bud regenerated a new tentacle and was found detached from the parent piece on the second day. Twenty-four hours after the operation two glandular regions were found at the base of the bud, one on each side of the narrow strand of tissue which connected bud and parent. These two foot regions remained distinct for only a day or two after the bud became detached, apparently merging into a single foot.

Experiment 32. - A seven-tentacled Hydra viridis bearing a bud with five very short tentacles was cut as in the two preceding experiments. Two of the bud's tentacles were left on the upper piece and three on the lower. Two and a half hours after the operation the upper piece appeared as in Figure $23 a$, and the lower piece as in Figure 23c. A day later the upper half-bud (Fig. 23b) was deeply constricted at its base and had a foot $\left(f^{\prime}\right)$, while the lower half-bud (Fig. 23 $d$ ) showed only a slight constriction between it and its parent piece. On the fourth day the upper half-bud was detached. The lower half-bud remained about as in Figure $23 d$ for four days. During the next two days the slight constriction between it and the parent piece completely disappeared, leaving a small three-tentacled polyp of perfectly normal form. A fourth tentacle was produced, but no change in form appeared up to the eleventh day after the operation.

Experiment 33. - A Hydra viridis with a bud upon which the tentacles were just beginning to form was cut as in the three preceding experiments. The upper half-bud formed three tentacles, and a foot developed at one side of the connection of bud and parent. Separation occurred early in the second day. The lower half-bud bore on the second day four long tentacles. Its axis coincided with that of the parent piece, and there was no constriction between them. No change in form occurred up to the sixteenth day.. The small polyp appeared a perfectly normal one.

Experiment 34. - A large eight-tentacled Hydra riridis with a bud bearing six or seven rery short tentacles was cut as in the preceding experiments. The results of this experiment differ in no important way from those of Experiments 32 and 33. The upper half-bud separated from the parent piece, although the process took 
more time than in any of the preceding experiments (about five days). The lower half-bud remained as the oral end of the lower parent piece for two weeks, no sign of separation appearing. On the fourth day a short tentacle was found at the region between bud and parent. This was evidently a regeneration from the oral end of the parent piece. It slowly degenerated or was resorbed.

Experiments 24-29 show that the cutting away of all but a small piece of the parent does not prevent the separation of the bud. Even if the bud is a very young one, it increases in volume and develops tentacles in a perfectly normal manner, finally constricting off from the parental fragment. The development and separation of the bud was not noticeably delayed by this operation upon the parent. A cut which injured part of the connection between bud and parent did not prevent the separation of the bud, but the progress of the constriction was somewhat delayed (Experiment 29).

The splitting of the bud longitudinally, each half being left attached to the corresponding part of the divided parent (Experiments $30-34$ ), resulted in the separation of the upper half-bud from the parent piece in all of the five experiments. The process of separation was delayed little, if at all, in some eases. In others there was probably a delay of two or three days. In Experiments 30-34 the lower half-bud in one case separated from the parent piece; in the other three cases it became permanently united to the parent piece to form its head, a normal polyp resulting. In five of the six cases where the half-bud separated from the parent piece, a conspicuous foot was formed before separation occurred, projecting out at one side of the connection, as shown in Figures $22 c$ and $23 b$. It may be a slight delay in the process of separation that gives opportunity for the formation of this foot. In a normal bud which is about to separate the region immediately about the point of connection is slightly glandular, but no such projecting foot is ever present.

In a second series of experiments upon buds, the bud was severed from the parent and then grafted back into the trunk of the parent. Will the subsequent history of the grafted bud resemble that of a lateral graft, or of a normal bud?

Experiment 35. - A large nine-tentacled Hydra viridis bore a six-tentacled bud whose endoderm was still connected with that of 
the parent. The bud was cut so that only a small fragment of its base was left attached to the parent. The bud was then carefully grafted back upon the trunk of the parent. It was found, when the compound became extended, that the graft had been set in below the stump of the bud (Fig. 24a). Two days later the grafted bud appeared as in Figure $24 \mathrm{~b}$. The region of union resembled that of graft and stock rather than that of bud and parent. During the next two weeks little if any change occurred at the base of the grafted bud. No constriction formed. When the graft was fully extended it was quite as large at its base as at any other point. The graft increased in size, becoming much larger than buds usually are before separation. On the eighth day after the grafting, the beginning of the migration of the graft toward the foot of the stock was detected. The compound was kept in water well supplied with large Infusoria and young Cyclops. On the sixteenth day a bud appeared at the middle of the trunk of the stock. This bud was detached and a second bud dereloped on the stock, $90^{\circ}$ or more around the trunk from the first. On the twentieth day the second bud was detached. A third one was now developing on the stock and also one on the graft. Figure $24 c$ shows the compound on the twenty-first day. The grafted bud has migrated almost to the foot of the stock. Both buds are about ready to be detached. The grafted bud is very much larger than normal buds at the time of their separation. On the twenty-second day the third bud on the stock was detached and the bud on the graft was about to separate. The bud of the graft was pulled off to determine if a foot had yet been formed. No tendency to stick to a needle could be detected. This ended the period of budding. During the next two weeks the migration of the graft to the foot of the stock was completed. On the thirty-sixth day (Fig. 24d) the constriction had begun. On the thirty-ninth day the graft was attached by a very slender thread of tissue. During the next twenty-four hours the graft became infested with bacteria, which caused its death before complete separation occurred. The stock remained perfectly healthy through the entire experiment.

Experiment 36. - A five-tentacled bud was cut from its seven-tentacled parent (Hydra viridis) and grafted back into the trunk at exactly the same level and $180^{\circ}$ from its original position. During the first two weeks the behavior of the grafted bud was precisely like that in the preceding experiment. At the end of that time it 
had migrated one-half the distance toward the foot of the parent, and no constriction had appeared. When extended, the axis of the parent was sharply bent at its intersection with that of the grafted bud. This compound did not live to complete its separation.

Experiment 37. - A Hydra fusea bearing a well-formed bud had been used in an unsuccessful experiment in which pieces had been eut from both ends of the parent. After the open ends had elosed, the bud appeared attached to a large spherical mass of the parent which had neither foot nor tentacles. The bud was then cut off so as to leave a small fragment of it on the parent piece. This fragment with a thin slice of the parent was then removed and in its place the bud was grafted back on the parent. For sixteen days the bud remained attached to the parent piece, which regenerated tentacles. No tendency to constrict off appeared during that time.

Experiments 35-37 show that a bud eut from the parent and grafted back upon the parent behaves precisely like a lateral graft bearing tentacles, and not like a bud. In some species of Hydra the buds of several generations remain attached to the parent for some time. In Hydra viridis I have never seen a bud of the second generation develop on a bud of the first generation before the separation of the latter from the parent. Such a condition as that shown in Figure 24c, where the grafted bud bears a bud of the second generation, is rare if not entirely abnormal for Hydra viridis. The graft has lost all the characteristics of a bud. It is a mature polyp reproducing asexually, as it does normally only after separation from the parent.

Does this entting and grafting at the base of the bud interfere with some structure there located which possesses the function of constricting off the bud?

Experiment 38. - A Hydra viridis bearing a five-tentacled bud was cut, as shown by the broken lines in Figure $25 a$, so as to leave a small piece of its trunk attached to the bud. This fragment bearing the bud was then very carefully grafted into the budding region of the trunk of another Hydra (Fig. $25 b$ ). On the next day (Fig. 25 c) the constriction at the base of the bud was a little deeper. On the second day the bud was detached. The small fragment of the parent remained as a conical elevation on the side of the stock and was completely resorbed in six days. 
In this case, then, where there was grafting without direct injury to the base of the bud, there was little or no delay in the separation of the bud.

These experiments upon buds show that at the base of the normal bud there is some structure capable of constricting off the bud from the parent. Serious injury to the parent, such as eutting away all but a small fragment which bears the bud, does not noticeably affect either the development of the bud or its separation, even though the operation is performed when the bud is quite young and without signs of tentacles or constriction. It is likely that in species of Hydra where the development of the bud requires a much longer time than in Hydra viridis such an injury to the parent would interfere with the growth of the bud, or even cause its resorption. The process is so rapid in $H$. viridis that a bud once well started is bound to develop. Its cells contain an amount of energy sufficient to ensure its development in spite of accident to the parent.

Any operation involving injury to part of the base of the bud, but leaving part uninjured, may delay the separation, but does not necessarily prevent it.

If a bud is split lengthwise, either part has the power of regenerating completely and separating from the parent. But when the base of the bud is cot transversely and the bud is grafted back into the parent at another place, the structure which effects the separation is interfered with. The bud does not continue to constrict off in the normal way, but migrates down the trunk and constricts off at the foot of the parent by a very slow process, as do lateral grafts. If the bud is grafted without injury to its base, the constricting process is not interfered with. The fact that the grafted bud does not continue to constrict off, can not be due to interference, by the operation, with the tendency in the parent to give off buds, for in Experiment 35 the parent continued to give off buds while the grafted bud remained attached. Likewise, when a piece is grafted into the budding zone of a Hydra, the refusal of the graft to behave like a bud is not because the polyp is not in a budding condition, for in Experiment 7 a bud developed and separated from the stock at a point almost opposite the insertion of the graft.

The nature of the structure which effects the constricting in the normal bud can at present only be conjectured. So far as I know, the literature upon the anatomy of Hydra offers no explanation of the 
problem. Whether the constricting is due to a special arrangement of the muscle fibres at the base of the bud, as suggested by Dr. DavenporT, or whether it is the result of intra-cellular activities, may possibly be determined by histological investigation. According to Nussbaum (1887) and Schneider (1890) the muscular system of Hydra consists of longitudinal fibres from the ectodermal cells and smaller circular fibres from the endodermal cells. Nothing is said as to the relation of these fibres to the bud. Nussbacm finds, in buds about to separate, a gradual transition in the ectoderm, from the typical muscle cells of the parent to the foot gland cells about the base of the bud.

That a transverve cut through the base of a bud, followed by grafting, inhibits the constricting process, may be due as much to the grafting as to the cutting. If we are right in supposing that the flowing together of tissues in grafting may so disturb the "polarity * of a small graft as to prevent its regenerating tentacles, we may equally well suppose that, in grafting a bud, the disturbances incident to the union of the tissues destroy that peculiar structure which is necessary for the accomplishment of constriction. The constricting off of a graft at the foot of the stock is similar to the process of separation of a bud, except that it requires a week or two instead of a day or two. It may possibly be effected by a structure which is of the same kind as that possessed by a bud, but which is only imperfectly developed because of the disturbance due to grafting.

A curious effect of "polarity « is to be observed in the behavior of the split buds (Experiments 30-34). Soon after the operation each half-bud swings through an angle of $90^{\circ}$, so that its axis coincides with that of the half-parent to which it is attached (Figs. $23 a$ and $23 \mathrm{c}$. . The upper piece of the divided polyp, therefore, consists of the half-parent and the half-bud united with aboral ends together Fig. 23a). It appears to be a trunk with tentacles at both ends. In the lower piece of the divided polyp, on the contrary, the polarity of the bud is not reversed relatively to that of the parent piece (Fig. $23 \mathrm{c}$ ). The two pieces of the bud each possess one-half of the bud's original base, in which resides the capacity for forming a constriction, and the two pieces have sustained the same amount of injury. That all of the upper half-buds should separate from the parent pieces, while three out of four of the lower half-buds become permanently united to the oral ends of the lower half-parent, must be dne to the difference in the polar relations in the two cases. 
The two half-buds must have possessed equal capacity for constricting off. That this capacity was not seriously interfered with by the welding toggether of the longitudinally cut edges when the cylindrical form is regained, is proved by the separation of the upper halves. After the cylinder is re-formed the half-bud must again possess a base about the whole circumference of which there is the capacity for constrieting, except possibly at the very point where the edges have come together. (This imperfect region may be responsible for the delayed separation noted in some cases.) The upper half-bud, with polarity opposed to that of the parent, constricts off with little delay. But the lower half-bud supplies the lower half-parent with the parts of which the parent has been deprived. This fact involves, in some way, the loss of the power of constricting off the bud. A normal form is regained, the bud having omitted the normal processes of separation, while the parent piece avoids the necessity for regenerating a head.

\section{Historieal.}

Trembley (1744) found that cutting pieces from the trunk of a polyp bearing a bud did not prevent the separation of the bud.

BAKER (1744, page 298) severed the trunk of a bud-bearing polyp a short distance above the uppermost bud. This bud swung about into the axis of the parent and became permanently the head of the parent, while that part of the parent trunk which projected beyond the bud was resorbed.

The case which I have already quoted from Marshall (1882, page 61) is a very similar one. In both of these eases, after the bud had become the head of the parent piece, that part of the parent trunk which was left above the bud came to resemble a lateral graft. In BAKER's experiment the lateral abnormality was resorbed; in MARShalL's, it regenerated tentacles and separated from the rest of the polyp; - precisely the two fates which my lateral grafts suffered.

\section{Heteromorphosis.}

Many attempts have been made to induce Hydras to produce tentacles on a cut aboral end. LoEB (1891) succeeded in getting. reversal of polarity, or Heteromorphosis, as he proposed to call it, in certain Hydroids. So far as I know, there is no case of any such Heteromorphosis on record for Hydra. An apparent case described 
by Wetzel (1895, page 292) admits of a more likely explanation. I tried some new experiments upon Hydra and got some good examples of Regulation, but no Heteromorphosis.

I first tried, having removed the tentacles and foot, to fasten a Hydra down to the bottom of the dish in an inverted position, thinking that the upper free aboral end might produce tentacles if the oral end could be prevented from doing so. This attempt failed for want of a means of fastening down the Hydra. I could find no substance so adhesive that a Hydra would stick to it under water. I tried pinning down large brown Hydras to a substratum of paraffin, by running a very fine thread of drawn glass obliquely through the end which $I$ wished to fasten down, but the polyp always succeeded in sliding up the glass filament, or else broke away from it entirely. I then tried grafting a foot upon the cut oral end of a Hydra, thereby providing it with a natural and effective means of adhering.

Experiment 39. - A large nine-tentacled Hydra viridis was selected, and as small a piece as possible was remored from the foot end. A second cut was made just below the tentacles and the small fragment bearing the foot was immediately grafted upon the cut oral surface. After the graft was well united, a large piece was cut from the aboral end of the trunk. This was done to prevent the immediate formation of a new foot at the place where the old one had been remored. Figure $26 a$ shows the condition of the polyp after these operations, the broken lines indicating the former position of the parts that were removed. Figure $26 b$ represents the polyp three days later. Rapid growth had occurred in the region of grafting, resulting in the bulging out of a mass which eventually bore at its end a new hypostome and tentacles. A second result of this growth was the bending over of the trunk so that its original aboral end tended to come down upon the glass. On the sixth day (Fig. 26 c) the polyp was attached by the grafted foot $(f)$ and also by a new foot $\left(f^{\prime}\right)$, which had formed on the cut aboral surface of the trunk. There was a considerable length of trunk between the new tentacles and the region of grafting. That this was entirely due to growth can not be said, for during the next three days it was discovered that the grafted foot was migrating down the old trunk toward the new foot (Fig. $26 d$, ninth day). This migration continued slowly during the next week, and at the same time the volume of the grafted foot decreased. On the seventeenth day the old foot remained as only a small prominence a short distance abore the new foot 
(Fig. 26e). On the nineteenth day no trace of the old foot could be found.

A perfectly normal six-tentacled Hydra was the result of the experiment. The foot which was grafted upon the oral end had been disposed of. The polyp was attached by a new foot which had been regenerated at the aboral end of the cut trunk, and a new hypostome and tentacles had been regenerated at the oral end. The outgrowth which pushed aside the grafted foot should possibly be interpreted as a regeneration from the combined oral ends of the trunk and the small fragment of transplanted foot. The latter piece was so small, however, that it could have taken little part in the regeneration. The migration of the old foot resembles that of lateral grafts. In this case, however, the free end of the migrating part was attached to the glass during most of the process. This was also the case with the lateral graft in Experiment 15.

Experiments 40 and 41 . - Two other experiments, like the preceding one, yielded precisely the same results.

Experiment 42. - This experiment was similar to the last three, except in the relative sizes of the pieces united. Upon the cut oral end of the lower half of a Hydra was grafted, in reversed polarity, a whole trunk from which the tentacles had been removed. After the surfaces had well united nearly two-thirds of this trunk was cut away, the result (Fig. $2 \vec{i}$ a) being that the upper third of one Hydra was grafted upon the lower half of another with oral surfaces together. The compound was attached vertically by means of the foot on the lower half. As in the other experiments, growth in the region of the graft resulted in the protruding af a mass (Fig. 27 b) which produced hypostome and tentacles, pushing the upper component of the compound to one side. The condition on the second day is shown in Figure $27 c$. The subsequent history of this compound was unlike that of others of the kind. The downward projecting aboral end of the upper component $(g)$ formed no foot, but was resorbed after a possible very slight migration down the trunk of the lower component. On the tenth day it appeared as in Figure $27 d$. The resorption of $g$ was completed during the next eight days.

In this case the piece that underwent resorption was inserted into the resorbing trunk by its oral end, while the resorbed lateral grafts were inserted by their aboral ends. That this piece migrated little, if any, suggests that the migration of the foot in Experiment 39 
may have been caused, or assisted, by its attachment to the glass during the process. If the polyp of Figure $26 \mathrm{c}$ were to become attached by both feet while in a contracted condition, it would seem that its subsequent extension would tend to stretch the old foot, $f$. This tension would be felt at the junction of this part with the main trunk, and would tend to pull the foot $f$ in an aboral direction along the main trunk.

In none of $m y$ experiments is there anything that can be interpreted as Heteromorphosis, unless it is the case of the lateral graft of Experiment 15. The forming of a foot at the free oral end of a short lateral graft in that experiment admits of that explanation. This graft was a small piece from the foot end of a Hydra. Only the adhesive tip of the foot had been removed. It is possible that, instead of true Heteromorphosis, we have to do here with a shifting about of the tissues of the short graft, so that some of the foot-forming gland cells came to lie toward the free tip of the graft.

One of WETZEL's experiments resulted similarly to Experiment 39. He removed the tentacles from two Hydras and united the trunks by their oral surfaces. The axis of the compound bent at the plane of union until the two trunks made a very acute angle with each other. At the apex of the angle a hypostome and tentacles were developed. Then the two trunks, which sprang from the common head, united by a downward progression of the region of fusion, to form a single polyp.

\section{The Uniting of Tissues in Grafting.}

In several of the experiments the remarkable attraction which appears to exist between the tissues of two approximated cut surfaces has been noted. If the two surfaces are brought into good contact with each other, they adhere immediately. Usually, on account of the inequalities of the surfaces, the first union occurred only at certain points, but this was always sufficient to ensure a good graft. My observations lead me to believe that only the like layers of graft and stock adhere when the surfaces are brought together. In most of the experiments the two pieces were at first united by the adhesion of fragments of endoderm. The uniting of adjacent masses of endoderm rapidly followed, the process appearing to be one of genuine cytotaxis. The ectoderms of graft and stock approach each other over the uniting endoderm. In the course of an hour the ectoderm 
may be seen to form a smooth layer of the normal thickness over the region of the union. As soon as the graft has recovered from the operation so as to become extended, it is perfectly evident that the endoderm at the base of the graft also forms a layer of the usual thickness and the cavities of stock and graft open freely one into the other. Sometimes the connection of graft and stock is at first very narrow (Fig. 7 a), but it soon increases in diameter (Fig. 7 b). In a few of the graftings the first union appeared to be by the ectoderm alone. These were cases where the union was not immediately obtained and the ectoderm began to close in over the endoderm. In Experiment 10, for example, the region at which the graft was attached appeared entirely free from green cells (Fig. 10 b). Between the endoderms of graft and stock there was a double thickness of ectoderm. In the course of an hour this ectoderm thinned out and the outlines of the endoderms approached each other. After three hours the endoderms of graft and stock were unquestionably united.

Experiment 43. - An experiment which failed of its purpose afforded a similar phenomenon as well as a good case of regulation. I cut a nearly mature bud from the parent and attempted to graft the bud back into the trunk. The bud evidently slipped in the paraffin groove, so that its side, instead of its cut aboral end, was pressed against the wound in the parent. When taken from the groove, the middle of the trunk of the bud was found to be adhering to the side of the stock. Figure $28 a^{\prime}$ shows the position of the bud; the axis of the bud is supposed to be parallel to the plane of the paper. Figure $28 a^{\prime \prime}$ shows the graft as it appears with its axis perpendicular to the plane of the paper. This was three and a half hours after the operation. The ectoderm had vanished between graft and stock and the endoderms had united. Figure $28 b$ shows the compound on the next day. From the region of the wound has grown out a short trunk, at the top of which, and transrersely to it, is balanced the grafted bud. By the fourth day (Fig. 28c) the axis of the oral end of the graft had swung about so as to come into line with that of the trunk on which the graft was borne. The foot end of the graft, still projecting out at one side, was undergoing rapid resorption. A foot had formed on the stock at $f^{\prime}$. By the ninth day the aboral end of the graft was completely resorbed. The point of dicergence of the two upper trunks migrated almost to the original foot. The constricting apart of the two trunks would doubtless have occurred as in many other experiments. 
Must both or only one of the contiguous surfaces be wounded, in order that union may occur? LrchtenserG is said to have made two polyps unite by binding them together with a hair. IschIKawa (1859) impaled two Hydras side by side on a bristle and they united. Neither of these methods precludes the possibility of wounding the surfaces in contact. I tried imbedding two Hydras side by side in a paraffin groove for an hour or more, but observed no tendency to adhere. I tried grafting where but one of the surfaces had been wounded, but could not get the pieces to adhere. In one case I took the lower half of a Hydra and pressed the foot into a break in the trunk of another, holding it there for several minutes. The piece adhered for some hours, but finally dropped off. I cut away the lower halves of Hydras and aliowed the cut ends of the remaining pieces to heal over. When the end was completely covered over with new ectoderm and before there were any signs of a foot, I tried to graft such a piece into the trunk of another Hydra, the freshly healed end being pressed into a wound. The pieces refused to adhere.

These experiments point toward the conclusion that both surfaces must be freshly wounded in order that union may occur. If two uncut surfaces could be held firmly and immovably together for a long period of time, the result might possibly be different. To do this without wounding the polyps is no easy task, so great is their eapacity for moving about, however they may be confined. In the case of the grafted bud in Experiment 43 (page 204), I am inclined to think that the ectoderm of the side of the bud must have suffered some abrasion which enabled the wounded surface of the stock to seize hold upon it at that region.

It is of importance to note that the mere adhesion of the surface of the bud to the tissues of the stock parent was sufficient to cause a perforation of the body layers of the bud, whereby its carity came to open freely into that of the stock parent.

\section{General Conclusions.}

The foregoing observations lead to the conclusion reached by WETzeL (1895, page 288): „Überall zeigt sich ein deutliches Streben, die normale Gestalt wieder herzustellen $«$. This strong tendency toward a certain definite condition appears to be due to an inward necessity rather than to external conditions. There is no obvious reason why 
such a compound as is represent in Figure $2 b$ should have entered upon the series of changes which ended in its separation into two polyps. There is no evident advantage acquired by such a separation. The ability of the compound to acquire food was not interfered with. The two oral trunks always diverged so that the two groups of tentacles commanded entirely separate fields. The double-headed compound therefore ought to have obtained twice as much food as a normal Hydra, while the bulk of body to be nourished was less than twice that of a normal Hydra. In water affording normal food conditions, therefore, the separation of the compound could not be explained as due to inability to obtain a normal amount of food. In my experiments, very small and poorly fed compounds separated as well as those that were large and budding. Therefore, we can not say that the separation was due to a demand for the division of the inconveniently great mass of the individual, except in so far as it may have been due to inherited tendencies which originated, possibly, from this cause.

The reproductire functions of graft and stock were undisturbed, for in many of the experiments the stocks produced buds, and in one case the graft also budded while attached to the stock. In several cases, too, sexual organs were formed on the stock.

Graft and stock separate in spite of the fact that the process involves serious difficulties, in the absence of the means of readr separation possessed by buds. It is not improbable that in the case of grafts we have to do with the same cause as that which effects the separation of buds. Only the manner of separation is different, owing to the absence, in the graft, of a certain structure which is present in the bud.

In the phylogeny of the Hydrozoa, the genus Hydra has become characterized by the solitary habit. Temporary colonies arise by budding. In some species of Hydra such colonies may include buds of more than one generation. I have never seen Hydra viridis bearing buds of a second generation, and very rarely is more than one bud produced at a time. The colonial condition in viridis endures for only a few days. Other Hydrozoa have permanently the colonial habit. Figure $24 c$ shows a temporary colony produced in Hydra viridis partly by the artificial process of grafting and partly by the natural process of budding. This colony eventually resolved itself into four individuals.

The form and solitary habit in Hydra are morphological necessities. 
By whatever means, mechanical or otherwise, this form and habit may be attained by the individual, they must be dependent, ultimately, upon certain qualities which have become fixed in the protoplasm of the genus. These qualities assert themselves in the regulation of artificially or accidentally produced abnormalities of form.

\section{Summary.}

1) Lateral grafts in Hydra viridis do not persist as permanent abnormalities.

a) If a piece bearing tentacles be grafted into the trunk of a Hydra, there results in most cases a slow migration of the graft down the trunk of the stock until graft and stock arise directly from a common foot. A constriction then slowly forms between graft and stock, which finally separate.

Sometimes the graft constricts and separates from the stock before the migration to the foot is completed.

The foot of the separated graft may be part of the foot of the stock, but in most cases it is a new organ produced at the base of the graft.

b) If a piece from which the tentacles have been removed be grafted into a trunk by its aboral end, it may regenerate tentacles, in which case its subsequent fate is precisely like that of grafts upon which the tentacles were allowed to remain.

c) Similar pieces may fail to regenerate tentacles, in which case they are completely resorbed by the trunk of the stock. There is sometimes a downward migration of a graft that undergoes resorption.

d) The size of a graft withont tentacles is a factor in determining its fate. Larger pieces tend to regenerate and separate from the stock; smaller pieces tend to be resorbed without regenerating.

The grafts that bear specialized oral organs, therefore, maintain their individuality.

There is some evidence that, after being grafted, pieces from the upper part of a polyp regenerate tentacles more readily than pieces of the same size from the lower part of the trunk.

All of the pieces that were resorbed were much larger than the minimum piece capable of regenerating if not employed as a graft.

e) In rare cases a lateral graft may replace that part of the trunk of the stock which is above the base of the graft. In such cases the graft remains permanently attached to the lower part of 
the stock, while the upper part of the stock assumes the appearance of a lateral graft and is ultimately constricted off leaving the remainder as a normal polyp.

2) A lateral graft may closely resemble a bud, but it differs from a bud in not possessing the means of ready separation from the trunk to which it is attached.

a) A very young bud of Hydra viridis or $H$. fusca left attached to a small fragment of the parent, develops and separates from the parent piece without noticeable delay.

b) If part of the attachment of bud to parent be injured, the separation is delayed but not prevented.

c) If buds be split longitudinally, the cut being extended across the parent transversely, the upper half-buds regenerate and separate from the parent piece with little delay. The lower half-buds may do likewise, but in most cases they regenerate and remain permanently as the head of the lower half-parent.

d) If a nearly mature bud be cut at its base from the parent and grafted back into the trunk of the parent, it does not continue to constrict off, but behaves precisely like a lateral graft bearing tentacles.

e) If a bud together with a very minute fragment of the parent be cut away, the fragment may be grafted into another Hydra without delaying the separation of the bud.

3) The operation of grafting appears to create some disturbance in the tissues of the graft within certain limits, preventing in some cases the regeneration of lost parts, and in the case of grafted buds destroying the structure which effects the ready separation of the bud.

4) A small lateral graft cut from the foot end of a Hydra viridis produced a foot at its free oral end, - a possible case of Heteromorphosis.

5) No union of pieces was obtained, except when both of the contiguous surfaces were freshly wounded. (Experiment 43 affords a possible exception.)

6) The regulation of abnormalities in Hydra appears to be independent of external conditions. It is, rather, an effect of certain qualities inherited by the organism. 
The foregoing experiments were carried on at Harvard University during 1898-1899. I wish to express my appreciation of the valuable aid and suggestions received from Doctor Chas. B. Datexport, under whose direction the work was done.

\section{Zusammenfassung.}

1) Bei Hydra viridis bilden seitliche Implantationen keine bleibenden Abnormitïten.

a) Wenn ein Theilstiick, welches Tentakel trägt, in den Körper von Hydra gepfropft wird, erfolgt in den meisten Fällen eine langsame Verschiebung des Pfropfstückes längs dem Körper des Stockes, bis das Pfropfstück und der Stock unmittelbar aus dem gemeinsamen $F a ß$ entspringen. Dann beginnt eine Einschnïrang zwischen Stock und Pfropfstiick, durch welche diese zuletzt getrennt werden.

Bisweilen schnürt sich das Pfropfstück ein und löst sich bereits vom Stocke ab, bevor die Verschiebung in der Richtung auf den Fuß vollendet ist.

Der Fuß des abgegliederten Pfropfstückes kann aus einem Theil des Fußes des Stockes entstehen; aber in den meisten Fällen handelt es sich um ein neues Organ, welches von der Basis des Pfropfstiickes gebildet wird.

b) Weun ein Theilstiick, dessen Tentakeln entfernt sind, in den Körper vermittels des aboralen Endes eingepfropft wird, können Tentakeln regenerirt werden; das weitere Verhalten ist vollkommen so, wie wenn die Tentakeln vorher stehen gelassen worden sind.

c) Gleiche Theilstücke können auch die Regeneration von Tentakeln unterlassen und werden in diesem Falle vollständig von dem Körper des Stockes resorbirt. Gelegentlich verschiebt sich nach riickwärts ein Pfropfstiick, das einer Resorption unterliegt.

d) Die Größe eines Pfropfstückes ohne Tentakeln ist ein Faktor der Bestimmung des weiteren Schicksals. Größere Stücke haben die Tendenz zu regeneriren und sich vom Stocke loszulösen; kleinere haben die Tendenz ohne Regeneration resorbirt zu werden.

Pfropfstïcke, welche specialisirte Oralorgane tragen, behalten ihre Individualität bei.

Es sind Andeutungen davon beobachtet, dass Pfropfstïcke aus dem oberen Theile eines Polypen Ieichter Tentakeln regeneriren als Theilstïcke von derselben Größe, aber aus dem unteren Theil des Körpers.

Alle Theilstücke, welche resorbirt wurden, waren viel größer als die kleinsten Theilstücke, welche fähig sind zu regeneriren, wenn sie nicht gepfropft werden.

e) In seltenen Fällen kann ein seitliches Pfropfstïck den Theil des Stockes, der oberbalb der Basis des Pfropfstïckes liegt, ersetzen. In diesen Fällen bleibt das Pfropfstiick dauernd mit dem unteren Theil des Stockes verbunden, während der obere Theil des Stockes einem seitlichen Pfropfstuick ähnelt und endlich abgeschnürt wird, den übrigen Theil als normalen Polyp hinter sich lassend.

2) Ein seitliches Pfropfstiuck kann einer Knospe sehr ähnlich sein; aber es unterscheidet sich von der Knospe dadurch, dass es nicht die Fähigkeit hat, sich leicht von dem Körper, dem es angefügt ist, loszutrennen. 
a) Eine sehr junge Knospe von Hydra viridis oder Hydra fusca, der ein geringes Fragment des Elternthieres anhaftet, entwickelt sich weiter und gliedert sich vom elterlichen Theilstuick ab, ohne nachweisbare Verzögerung in der Abgliederung.

b) Wenn ein Theil des Verbindungsstückes zwischen dem Elternthiere und einer Knospe verletzt ist, so ist die Abgliederung verzögert, aber nicht ausgeschlossen.

c) Wenn eine Knospe der Länge nach gespalten wird und die Schnittfäche quer zum Elternthiere durchgefüht wird, dann regenerirt und lïst sich die obere Hälfte der Knospe vom Elternthiere ohne große Verzögerung ab. Die untere H:̈lfte kann sich ebenso verhalten; aber in den meisten Fällen regenerirt sie und bleibt als Kopf an der unteren Hälfte des Elternthieres bestehen.

d) Wenn eine nahezu reife Knospe an ihrer Basis vom Elternthiere abgeschnitten wird und seitlich in den Körper des Elternthieres gepfropft wird, dann fährt sie nicht weiter fort sich abzuschnïren, sondern verhält sich durchaus wie ein seitliches, Tentakel tragendes Pfropfstïck.

e) Wenn eine Knospe mitsammt einem kleinen Fragmente des Elternthieres abgeschnitten wird, kann das letztere in eine andere Hydra gepfropft werden, ohne dass die Abgliederung der Knospe eine Verzögerung erfährt.

3) Die Operation einer Pfropfung scheint eine Störung der Gewebe innerhalb gewisser Grenzen hervorzurufen, die zuweilen eine Regeneration des abgeschnittenen Theiles verhindert and, wenn es sich um implantirte Knospen handelt, die Fähigkeit der Knospe, sich leicht vom Elternthiere loszutrennen, vernichtet.

4) Ein kleines laterales Pfropfstiick, welches vom Fußende einer Hydra viridis entnommen war, brachte an seinem freien oralen Ende einen Fuß hervor - möglichenfalls ein Beispiel von Heteromorphosis.

5) Eine Vereinigung von Theilstuicken erfolgt nur dann, wenn beide Vereinigungsfächen frisch verwundet sind. (Vielleicht ist das Experiment 43 eine Ausnahme.)

6) Die Regulation von Abnormitäten der Hydra scheint von äußeren Bedingungen unabhängig zu sein; sie ist vielmehr der Effekt von bestimmten. ererbten Qualitïten des Organismus.

\section{Literature.}

Baker, H. 1744. Essai sur l'histoire naturelle du Polype, Insecte. Traduit de l'angl. par P. Demouns. Avec 22 pl. Paris.

Ischikawa, C. 1889. Trembley's Umkehrungsversuche an Hydra nach neuen Versuchen erklärt. Zeitschr. f. wiss. Zool. Bd. 49, Heft 3. pag. 433-460. Taf. $18-20$ u. 4 Textfig.

KLeinenberG, N. 1872. Hydra. Eine anatomisch-entwickelungsgeschichtliche Untersuchung. Mit 4 Taf. Leipzig.

LaNG, Albert. 1891. Über die Knospung bei Hydra und einigen Hydropolypen. Zeitschr. f. wiss. Zool. Bd. 54, Heft 1-2. pag. 365-385. Taf. 17.

Loeb, J. 1891. Untersuchungen zur physiologischen Morphologie der Thiere.

I. Über Heteromorphose. Mit 1 Taf. u. 3 Textfig. Würzburg. 
Marshall, W. 1882. Über einige Lebenserscheinungen der Sïßwasserpolypen und über eine neue Form von Hydra viridis. Zeitschr. f. wiss. Zool. Bd. 37 , Heft 4. pag. $664-702$. Taf. 37.

NussbauM, M. 1887. Über die Theilbarkeit der lebendigen Materie. II. Mittheilung. Beiträge zur Naturgeschichte des Genus Hydra. Archiv f. mikr. Anat. Bd. 29. pag. 265-366. Taf. 13-20.

Peebles, Florexce. 1897. Experimental Studies on Hydra. Arehiv f. Entwickelungsmechanik. Bd. V, Heft 4. pag. 794-819. 34 figures in text.

RaNo, H. W. 1899. Regeneration and Regulation in Hydra viridis. Archiv f. Entwickelungsmech. Bd. VIII, Heft 1. pag. 1-34. Taf. 1-4.

Schneider, K. C. 1890. Histologie von Hydra fusca mit besonderer Berücksichtigung des Nervensystems der Hydropolypen. Archiv f. mikr. Anat. Bd. 35. pag. $321-379$. Taf. $17-19$.

Trejibley, A. 1744. Mémoires pour servir à l'histoire naturelle d'un genre de polypes d'eau douce, a bras en forme de cornes. Avec $20 \mathrm{pl}$. Leyde.

Vernon, H. M. 1898. The Relations between Marine Animal and Vegetable Life. Mittheilungen a. d. Zool. Station zu Neapel. Bd. 13, Heft 3. pag. 341 -425 .

Wetzel, G. 1595. Transplantationsversuche mit Hydra. Archiv f. mikr. Anat. Bd. 45. pag. 273-294. Taf. 18.

Williars, S. R. 1899. The Specific Gravity of Some Fresh-water Animals. Amer. Naturalist. In press.

\section{Explanation of Plates V-VII.}

b Bud.

d Bottom of Stender dish.

e Endoderm.

$f$ An old foot.

$f^{\prime}$ A new foot.

9 Graft.

Abbreviations.

In all of the following figures, the double lines on the trunk indicate the thickness of the transparent ectoderm.

Figs. $1 a, 1 b$. To illustrate the method of making a graft. $1 a$, View, from above, of a stock and graft lying in their grooves in the paraffin. $1 b$, a vertical section across the groove at $A \mathcal{A}$. $d$, the glass bottom of the Stender dish; $p$, the paraffin film.

Figs. $2 a-2 \pi$. The regulation of a lateral graft bearing tentacles. Hydra fusca. $2 a, 1 / 2$ hour after the operation. $2 b, 2^{\text {nd }}$ day. $2 c, 4^{\text {th }}$ day. $2 d, 18^{\text {th }}$ day. $2 e, 38^{\text {th }}$ day. $2 f, 46^{\text {th }}$ day. $2 g, 4^{\text {th }}$ day. $2 h, 52^{\text {nd }}$ day.

Figs. $3 a-3 \pi$. The regulation of a lateral graft bearing tentacles. Hydra viridis. $3 a$, about 1 hour after the operation. The broken lines indicate the relation of the graft to the Hydra from which it was cut. $3 b, 2^{\text {nd }}$ day. $3 c, 4^{\text {th }}$ day. $3 d$, $7^{\text {th }}$ day. $3 e, 10^{\text {th }}$ day. $3 . f, 14^{\text {th }}$ day. $3 g, 17^{\text {th }}$ day. $3 h, 18^{\text {th }}$ day. $3 i, 2 u^{\text {th }}$ day. $3 k, 23^{\text {rd }}$ day. 
Figs. $4 a-4 f$. The regulation of a lateral graft bearing tentacles. Hydra viridis. $4 a, 2^{\text {nd }}$ day. $4 b, 12^{\text {th }}$ day. $4 c, 16^{\text {th }}$ day. $4 d, 20^{\text {th }}$ day. $4 e, 25^{\text {th }}$ day. $4 f, 29$ th day.

Figs. $5 a-5 c$. The regulation of a lateral graft bearing tentacles. Hydra $v i r i d i s$. $5 a, 2$ hours after the operation. $5 b, 22$ hours. $5 c, 14^{\text {th }}$ day.

Figs. $6 a-6 b$. A lateral graft bearing tentacles. Hydra viridis. 6a, 2 hours after the operation. The broken lines indicate the relation of the graft to the Hydra from which it was cut. $6 b, 6^{\text {th }}$ day. Two tentacles have united from their bases distalward.

Figs. $7 a-7 f^{\prime \prime}$. A lateral graft which regenerated tentacles. Hydra viridis. $7 a$, immediately after the operation. $7 b, 2$ hours. The broken lines indicate the parts of the graft-polyp which were cut away. $7 c, 29$ hours. $7 d, 3^{\text {rd }}$ day. $7 e, 7_{\text {th }}$ day. $7 f^{\prime}$, the stock, and $7 f^{\prime \prime}$, the graft, after separation, $13^{\text {th }}$ day.

Figs. $8 a-8 f$. A lateral graft which regenerated tentacles. Hydra viridis. $8 a, 2$ hours after the operation. The broken lines show the relation of the graft to the polyp from which it was cut. $8 b, 2 \pi$ hours. $8 c, 3$ rd day. $8 d, 7^{\text {th }}$ day. $8 e, 10^{\text {th }}$ day. $8 f, 36^{\text {th }}$ day.

Figs. $9 a-9 d$. A lateral graft which was resorbed. Hydra viridis. $9 a$, immediately after the operation. The broken lines indicate the parts of the graft-polyp which were cut aray. $9 b$, 2nd day. $9 c, 4$ th day. $9 d$. 6 th day.

Figs. $10 a-10 f$. A lateral graft which was resorbed. Hydra viridis. $10 a$, 3 hours after the operation. The broken lines indicate the parts of the graft-polyp which were cut away. $10 \mathrm{~b}$, immediately after the operation. The endoderms of graft and stock have not united. $10 c, 2^{\text {nd }}$ day. $10 d$, $6^{\text {th }}$ day. $10 e, 11^{\text {th }}$ day. $10 f, 26^{\text {th }}$ day.

Figs. $11 a-11 e$. A lateral graft which was resorbed. Hydra viridis. 11 a. immediately after the operation. The broken lines indicate the parts of the graft-Hydra which were cut away. $11 b, 17^{\text {th }}$ day. $11 c, 20^{\text {th }}$ day. $11 d, 37^{\text {th }}$ day. $11 e, 41$ st day.

Figs. $12 a-12 e$. A lateral graft which produced a foot at its oral end. Hydra viridis. $12 a, 1$ hour after the operation. The broken lines indicate the parts of the graft-Hydra which were cut away. $12 b, 18$ hours. $12 c, 8^{\text {th }}$ day. $12 d, 10^{\text {th }}$ day. $12 e, 20^{\text {th }}$ day.

Figs. $13 a-13 e$. A lateral graft which regenerated tentacles. Hydra viridis. $13 a, 1$ hour after the operation. The broken lines indicate the parts cut away from the graft-Hydra. $13 b, 21$ hours. $13 c, 4^{\text {th }}$ day. $13 d, 15^{\text {th }}$ day. $13 e, 23 \mathrm{rd}$ day.

Figs. $14 a-14 c^{\prime \prime}$. A lateral graft which regenerated tentacles. Hydra viridis. $14 a$, immediately after the operation. The broken lines indicate the relation of the graft to the Hydra from which it was cut. $14 b$, 5th day. $14 c^{\prime}$, the compound moderately extended, and $14 c^{\prime \prime}$, the compound contracted, $19^{\text {th }}$ day.

Figs. 15a-15c. A lateral graft which was resorbed. Hydra viridis. 15a, $1 \frac{1}{2}$ hours after the operation. The broken lines indicate the relation of the graft to the Hydra from which it was cut. $15 b$, 5th day. 15c, $18^{\text {th }}$ day.

Fig. 16. A bad of Hydra viridis attached to a small fragment of the parent trunk. 
Figs. $17 a-17 b$. A bud of Hydra viridis attached to a small fragment of the parent trunk. $17 a$, condition of the bud when the parent was cut. $17 b$, 1 day after.

Figs. 18a-18b. A bud of Hydra fusca with a small fragment of the parent trunk. $18 a$, condition of the bud when the parent was cut. $18 b, 3^{\text {rd }} d a y$ after.

Figs. 19a-19c. A bud of Hydra fusca with a small fragment of the parent trunk. $19 a$, condition of the bud when the parent was cut. $19 b, 3^{\text {rd }}$ day after the operation. $19 c, 5^{\text {th }}$ day.

Fig. 20. A very young bud of Hydra viridis attached to a fragment of the parent; $1 / 2$ hour after the cutting of the parent. The bud developed normally.

Fig. 21a. A Hydra viridis bearing two buds cut across at two places, as shown by the broken lines. $21 b$, the fragment bearing the buds, ten minutes later. $21 c, 20$ hours after. The older bud has become detached. The broken line shows the direction of a cut which removed part of the parent piece and injured the base of the bad. $21 d, 3$ hours after $21 \mathrm{c}$. $21 e, 24$ hours after $21 c$. $21 f, 3$ rd day after $21 c$.

Fig. 22a. A budded Hydra viridis cut as shown by the broken line. $22 b^{\prime}$, the lower part, and $22 b^{\prime \prime}$, the upper part, 24 hours later. $22 c$, the lower part on the 3 rd day after the operation.

Figs. $23 a-23 d$. A budded Hydra viridis cut as in Fig. $22 a .23 a$, the upper part $21 / 2$ hours after cutting; $23 b, 1$ day later. $23 c$, the lower part $2 \frac{1}{2}$ hours after the operation; $23 d, 1$ day later. The lower half-bud did not separate from the parent piece.

Fig. 24 a. A bud of Hydra viridis cut from the parent and grafted back into the trunk below its original position. 24b, 2 days later. 24c, 21st day; both the stock and the grafted bud bear buds. $24 d$, the base of the compound on the $36^{\text {th }}$ day.

Fig. 25a. A bud of Hydra viridis cut from the parent, together with a small fragment of the trunk, as shown by broken lines. $25 b$, the fragment bearing the bud grafted into the side of another Hydra. 25c, the same 1 day later.

Fig. $26 a$. The foot of a Hydra viridis grafted on to the oral end of the upper half of the trunk. $26 b, 3$ days later. $26 c$, (ith day. $26 d, 9^{\text {th }}$ day. $26 e, 17^{\text {th }}$ day.

Fig. 27 a. The upper third of a Hydra viridis grafted on to the lower half of another, the two oral surfaces being together. $27 b, 1$ day later. $27 c$, $2^{\text {nd }}$ day. $27 d, 10^{\text {th }}$ day.

Fig. $28 a^{\prime}$. A bud of Hydra viridis cut from the parent and grafted back on to the trunk, the side of the bud being attached to the parent. The bud is seen lengthwise. $28 a^{\prime \prime}$, the bud is seen endwise. $28 b, 1$ day after the operation. To show its true length, the bud is represented as turned $90^{\circ}$ in a plane perpendicular to the branch of the trunk upon which it rests. $28 c, 4$ th day. 
214 Herbert W. Rand, The Regulation of Graft Abnormalities in Hydra.

\section{Table of Contents.}

II. Material . . . . . . . . . . . . . . . . . . . . . . 163

III. Methods . . . . . . . . . . . . . . . . . . . . . . . . . . . . 163

1. Grafting . . . . . . . . . . . . . . 163

2. Aquaria .................... . . 166

IV. Lateral Grafts . . . . . . . . . . . . . . . . . . . . . . . 168

1. Grafts Bearing 'Tentacles . . . . . . . . . . . . . . . . . 168

2. Grafts which Regenerated Tentacles............ . 175

3. Grafts which did not Regenerate Tentacles. . . . . . . . . 177

4. Factors which Determine the Fate of Grafts . . . . . . . . 178

a. Pieces from the Lower Part of the Trunk . . . . . . . . 178

b. Pieces from the Upper Part of the Trunk . . . . . . . . 181

5. The Regulation of Lateral Grafts . . . . . . . . . . . . . . 184

a. Separation of Graft and Stock. . . . . . . . . . . 158

6. Historical. . . . . . . . . . . . . . . . . . . . . . . . . . 189

V. The Behavior of Buds and Grafts Compared . . . . . . . . . . . 190

Historical. . . . . . . . . . . . . . . . . . 200

VI. Heteromorphosis . . . . . . . . . . . . . . . . . . . 200

VII. The Uniting of Tissues in Grafting . . . . . . . . . . . . . 203

VIII. General Conclusions. . . . . . . . . . . . . . . . . . 205

IX. Summary . . . . . . . . . . . . . . . . . . . . 207

Zusammenfassung . . . . . . . . . . . . . . . . . . . . 209

Literature . . . . . . . . . . . . . . . . . . . . . . . 210

Explanation of Plates . . . . . . . . . . . . . . . . . 211 